\title{
Prescriptions for adaptive comanagement: the case of flood management in the German Rhine basin
}

\author{
Gert Becker $^{1}$, Dave Huitema $^{1,2}$ and Jeroen C.J.H. Aerts ${ }^{1}$
}

\begin{abstract}
Centrally administered bureaucracies are ill suited to managing the environmental resources of complex social-ecological systems. Therefore management approaches are required that can better deal with its complexity and uncertainty, which are further exacerbated by developments such as climate change. Adaptive comanagement (ACM) has emerged as a relatively novel governance approach and potential solution to the challenges arising. Adaptive comanagement hinges on certain institutional prescriptions intended to enhance the adaptability of management by improving the comprehension of and response to the complex context and surprises of social-ecological systems. The ACM literature describes that for enhanced adaptability, institutional arrangements should be polycentric, aligned with the scale of ecosystems (the bioregional approach), feature open and participatory governance, and involve much experimentation. The case of flood management in the German part of the Rhine basin is used to provide an assessment of these ideas. We analyze whether and to what degree the prescriptions have been implemented and whether or not certain fundamental changes seen in German flood management can be traced back to the application of the prescriptions. Our study demonstrates a transition from the traditional engineering and "flood control" approach to a more holistic management concept based on a risk perspective. In this process, the four ACM prescriptions have made an important contribution in preparing or facilitating policy changes. The findings suggest that the application of the prescriptions requires the right supporting context before they can be applied to the fullest extent possible, such as a high problem pressure, new discourses, or leading actors. A major constraint arises in the misalignment of political power and of the different interests of the actors, which contribute to reactive management and inadequate interplay. To address this, we recommend further analysis of the role of coordinated and long term planning. This might reveal evidence to overcome institutional coordination failures, improve knowledge transfer and communication, and increase adoption of the ACM prescriptions, with the aim to enhance adaptability of the system.
\end{abstract}

Key Words: adaptability; adaptive comanagement; flood management; German Rhine basin

\section{INTRODUCTION}

The debate over the appropriate institutions to address the challenges facing environmental resource management, including flood management, has continued unabated for many years. An intensive discussion is ongoing on the preferences concerning the right mix of governance modes, e.g., state/market/ decentralization, knowing that flood management faces increasing complexity and future uncertainty through climate change and socioeconomic developments (Merz et al. 2010, Ingram 2011, Hill 2012). The literature shows that both a centrally administrated bureaucracy (Ostrom 1999, Berkes et al. 2003, Gleick 2003, Pahl-Wostl 2011), as well as yield-oriented market mechanisms (Gustafson 1998, EEA 2005, Armitage et al. 2007, UNECE 2009) have limitations to respond to the changing conditions of dynamic and nonlinear social-ecological systems on their own.

A new management concept, based on network governance and often labeled as adaptive comanagement (ACM), has been identified as one that appears to address the unpredictable behavior of such complex systems (e.g., Armitage et al. 2007, 2008, Plummer et al. 2012, 2013, Scarlett 2013). Adaptive comanagement is considered capable of handling divergent interests and of providing the flexibility needed to adjust to changing circumstances, as with climate change (Dietz et al. 2003, Folke et al. 2005, Young et al. 2006, Olsson 2007, Pahl-Wostl 2009). The term "adaptive" refers to the ability to manage uncertainty through "learning by doing" (Berkes and Folke 1998:10), by testing of hypotheses, and using an experimental approach to management. The learning from doing results create the room for innovation, alternatives, and opportunities for revision (Holling 1978, Lee 1993, Lebel et al. 2005, Olsson et al. 2006, Tabara and Pahl-Wostl 2007). The term "comanagement" indicates the collaboration of a wide range of actors from government and civil society in sharing managing power and responsibilities across local, regional, and national levels, emphasizing inclusive decision making and knowledge provision from different sources (Folke et al. 2005, Guerin 2007, Armitage et al. 2007, 2009).

The aim of ACM is to enhance the adaptability of actors. We define adaptability as the ability to prepare for, to respond to, and to cope with climate and societal variability to reduce the effects from floods. In addition to Engle (2011) and Walker et al. (2004), we follow Folke et al. (2010) and Hill (2012, 2013) in conceptualizing adaptability through its role in the transformation potential of a flood management system, enabling the adjustments or implementation of new rules, measures, or configurations to achieve a more sustainable state of the governance system. Hence, adaptability entails the capacity to experiment and learn, to collaborate and link, to respond to external drivers and internal processes, and can be characterized as the precondition for adaptation (Smit and Wandel 2008), which is here referred to the implementation of flood risk reducing measures, both proactive and reactive.

Huitema et al. (2009) have argued in this journal that ACM revolves around four institutional prescriptions that can each in 
its own way enhance adaptability. They suggest that: (1) institutional structures need to be polycentric, i.e., management of the ecosystem is undertaken from multiple centers of power in which political authority is dispersed to separately constituted bodies; (2) natural rather than jurisdictional boundaries are the basis for task allocation, i.e., the bioregional approach; (3) high levels of public participation are required to ensure diversity of problem perception, knowledge, and solutions and to attain critical reflection; and, finally, (4) the institutional set up must provide an experimental approach to management.

The concept of ACM is attractive, but its practical application has proven to be tantalizingly difficult, and where attempts have been made to introduce it, making an assessment has not been easy. Lee (1993), for instance, presents a long list of conditions that must be met before ACM has a chance of being used. Likewise Huitema et al. (2009) mention various practical issues associated with the real-world application of these prescriptions, many of which were confirmed by Munaretto and Huitema (2012). Plummer et al. (2012), in a meta-analysis of the literature on ACM, suggest that an assessment of the results emanating from the practical application of ACM so far is inconclusive because of the strongly divergent ways in which relevant ACM factors have been conceptualized (e.g., learning, social networks, conflict of interest) and the dearth of operational measures to assess their contribution. Thus, attributing success or failure to ACM components and ACM seems next to impossible, and further research on the feasibility and efficacy of ACM is warranted.

We are specifically interested in the contribution of ACM to the progress of German flood management systems during the last three decades. We thus collected information on whether the four ACM prescriptions have been applied and how they been operationalized in the German part of the Rhine basin. This is a region in which authorities have stated their goal to create a more flood resilient regime, because of its high economic importance and growth potential (Becker 2009). Furthermore, there is a widely shared perception that German water management bodies needs to pay more attention to high levels of uncertainty because of the potential impacts of climate change and the risk of more extreme flood events in the future (te Linde 2011, Kundzewicz 2012, Bubeck 2013).

The two main research questions are: (1) To what degree have the four institutional prescriptions of ACM been followed in the German part of the Rhine basin?; and (2) Can fundamental changes in German flood management be related to the implementation of the prescriptions?

Our research will not evaluate whether, or to what degree, adaptability has been improved. Instead, we aim to analyze whether there are signals of adaptability that can be linked to the four institutional prescriptions. Thus, we describe the transition of flood management in the German Rhine basin in the last three decades and analyze whether policy changes have followed the prescriptions.

\section{METHODS}

\section{Case study: the German Rhine}

The Rhine River serves as an example of a mature basin regime with a long experience of river interventions, covenants, efforts to reduce flood risk, and it has a history of cooperation in managing the multiple functions of the river, such as navigation, fishery, industry, and ecology (Dieperink 1997, de Bruin 2006). The Rhine is the third largest river in Europe with a length of $1239 \mathrm{~km}$, of which $880 \mathrm{~km}$ is navigable. The basin is shared by nine countries, of which Germany covers the largest part with $55 \%$ of the basin area; other parts include Switzerland $18 \%$, France $13 \%$, the Netherlands $6 \%$, and Liechtenstein, Italy, Belgium, Austria, and Luxembourg with only minor parts. It is the busiest and economically most important waterway in Germany and Western Europe with densely populated, large industrial centers in the Rhine-Neckar, Rhine-Main, and Ruhr regions.

The three primary levels of competence in German water management lie with the federal government, the federal states (Länder), and the districts and municipalities. Legal framing power and international policy application exist at the national level, whereas the power of policy application and implementation of measures in most areas, including water resources, environment, and spatial development, is in the hands of the federal states and, following the subsidiarity principle, with the lower administrative levels (Kraemer 1999, Winnegge and Maurer 2002, UBA 2010). New legislation and policy concepts have to pass the parliament of the federal states, and the implementation of major constructive and spatial projects are subject to heavy authorization procedures down to the local level. The strict division of responsibility between functional domains in the federal states, e.g., water management, spatial planning, and economic development, together with a dominant top-down management style make it challenging to resolve conflicts of interest in water management, for instance, between flood management and land usage (Moss 2004, 2012).

Almost two centuries of large-scale engineering interventions at the Upper Rhine, completed in 1977, to adapt the river system to different user functions has led to evident negative environmental impacts, such as a lower groundwater table and land subsidence and to a serious increase of the flood risk caused by the loss of some $85 \%$ of the former flood plains and alluvial forests and higher water flow (Bernhardt 2002, Frijters and Leentvaar 2003, Witter et al. 2006, de Bruin 2006). Following the expert advice of the International Commission for Research on Floods of the River Rhine (HSK) in 1978, the new idea of flood water storage was introduced, i.e., the river is given additional room to reduce peak water levels and enable larger discharges. In 1982, the two riparian countries Germany and France gave their formal approval to re-establish the former level of protection against a once-in-200-year flood in the Upper Rhine, with Germany taking on most of the workload (Disse and Engel 2001, Dister 2002). The HSK proposal was designed as a water storage project to lower flood peaks. However, the merely technical approach with the focus on water management did not consider the ecological aspects and socioeconomic consequences of the system. This deficiency was interpreted by the responsible authority as a trigger to present alternative flood management concepts, for example, to combine hazard reduction with flood plain restoration or to introduce the idea of precaution, damage minimization, and selfresponsibility. In that respect, the bilateral agreement can be considered as the starting point for the transition from a traditional, engineered safety discourse to a new flood management policy in Germany based on an ecological risk perspective (Becker 2009). To establish an adaptive flood risk 
management regime is imperative, because the consequences of extreme floods in the German part of the Rhine can be enormous: approximately three million people live in flood prone areas and possible flood damage in extreme cases has been estimated at a cost of between 35 to 65 billion Euros (Disse and Engel 2001, Frijters and Leentvaar 2003, IKSR 2006, te Linde et al. 2011).

\section{Analytical framework}

It has been suggested that ACM revolves around four institutional prescriptions that can each enhance adaptability in flood management. We will use the four institutional ACM prescriptions to describe whether the theory of adaptive comanagement has made progress in German flood governance. We briefly summarize each prescription (for more details, see Huitema et al. 2009) and their relationship with the adaptability of the system.

\section{Polycentric structure}

Polycentric structures are characterized by multiple governing authorities and centers of decision making at different scales that are formally independent of each other and function with coherent interaction as a system (Ostrom 1999, 2010). In a polycentric system, the lowest jurisdictional level, i.e., communities or municipalities, is emphasized, and the opportunities for self-governance and local self-determination are considered of paramount importance (McGinnis 2005, Anderson and Ostrom 2008, Sovacool 2011). Polycentricity represents a broader concept than mere federalism. According to McGinnis and Ostrom (2011:15), "a federal system may only consist of a sequence of nested jurisdictions at different levels, but a polycentric system also includes crosscutting jurisdictions specializing in particular policy matters, such as managing a river basin that cuts across state lines." The literature on polycentric structures suggests that a distribution of power, overlapping responsibilities, and an added advantage of local knowledge promote a diversity of problem framing, policies, and learning from each other that can foster adaptability. This can entail lower barriers to testing new ideas and experimenting with multiple approaches to provide creative alternatives and locally customized solutions; extra opportunities arise for networking and the supporting roles of private corporations, building coalitions, voluntary associations, and community-based organizations, collecting social-ecological knowledge, gaining experience from diverse sources, and for providing the safety net of redundancy (Dietz et al. 2003, Ostrom 2005, Anderson and Ostrom 2008, Huitema et al. 2009, Neef 2009). The discourse on polycentricity also suggests potential problems. Without appropriate and well-functioning negotiation and coordination mechanisms, ambiguous or overlapping responsibilities and activities can result in unclear accountability, opportunism, dysfunction, and delay (McGinnis 2000, 2005, Ostrom 2005, Toonen 2010, Pahl-Wostl 2011, Sovacool 2011).

\section{Bioregional approach}

The bioregional approach centers on the notion of fit between institutions and social-ecological systems (Folke et al. 2007), recognizing the interdependencies of the environmental, technological, economic, institutional, and cultural characteristics of a river basin (Pahl-Wostl 2007, Huitema and Meijerink 2014). Gibson et al. (1998) regard this as an optimization issue and Young (2002:20) proposes "the closer the fit between eco- and institutional systems the better the relevant institutions will perform." Thus, congruence or compatibility is needed between the ecosystem and the institutions created to manage the human activities affecting this system, and natural rather than jurisdictional boundaries are considered as the basis for task allocation. This line of thinking was also embedded in the EU Water Framework and Floods Directives, which both propose river basin scale approaches with the purpose of better linking upstream and downstream communities and creating a more integrated governance system (CEC 2000, 2007). In a transboundary river basin, such as that of the Rhine, the question of fit is complex because various processes play out at very different levels, scales, and political domains, and it is difficult to exclude spatial misfits (Moss 2004, Blomquist and Schlager 2005, Imperial 2005, Cosens and Williams 2012). River basin organizations can here play an important role to enhancing the awareness of interdependencies, linking decision-making institutions, and facilitating the information flow (Schlager and Blomquist 2000, Sadoff and Grey 2002, Borowsky et al. 2008, Huitema et al. 2009) Empirical evidence has dampened expectations that the bioregional approach could serve as a panacea for environmental resource problems in this and many other domains (Ostrom et al. 2007). Nevertheless, implementation of the concept may help to drive and shape adaptive comanagement through a better integration of the diverse interests up- and downstream and a more efficient use of resources.

\section{Participation}

Public participation means to involve those who are affected by a decision, assuming that this will lead to a better quality and durability of said decisions and will reflect the interests and concerns of the affected and interested people. In this respect, participation is expected to contribute in various ways in increasing the legitimacy, accountability, and transparency of the decision process and in achieving socially acceptable solutions (Sabatier et al. 2005, Mostert et al. 2007, Reed 2008). Participation can enhance the efficiency and quality of problem solving by establishing links and networks among decision makers and the public, by enabling dialogue, and by building a broader, more balanced knowledge base among the different actors involved, thus increasing the mutual awareness and contextual understanding necessary to jointly tackle the issues at hand and to support the decisions taken (Hajer and Wagenaar 2003, Mostert 2003, Borowski et al. 2008). Participation can therefore create trust among actors and foster social learning; both considered important building blocks for adaptability and motivation for adaptation (Folke et al. 2005, Huitema et al. 2007, Armitage and Plummer 2010, Lebel et al. 2010, Schultz et al. 2011, Renn 2014). A number of limitations and drawbacks have also been observed, including: a lack of clarity both of purpose and the role of stakeholders; unequal distribution of information and knowledge; a lack of accountability of participants or their representativeness; an overemphasizing of consensus; a lack of experience with multiparty approaches, including the promotion of such approaches; and an uncertainty about how binding jointly agreed decisions really are for participants, but also for elected representatives (Bulkeley and Mol 2003, Kampa et al. 2003, Van de Kerkhof 2006, Huitema et al. 2007, Mostert et al. 2007, Reed 2008). 
Table 1. Characteristic aspects of adaptive comanagement (ACM) prescriptions and indicators of operationalization.

\begin{tabular}{l}
\hline Characteristic Aspects \\
\hline Polycentric set up \\
- Emphasis on the lowest possible jurisdictional level \\
- Higher jurisdictional levels responsible for oversight and diffusion of \\
innovations \\
- High tolerance for overlap and redundancy
\end{tabular}

Bio-regional approach

- Natural boundaries rather than jurisdictional boundaries are the basis for task allocation

- Problems and resultant interventions are considered from the perspective of consequences in the entire regions

\section{Participation}

- Taking part and exert influence, by ordinary citizens, stakeholders or their collectives, in the processes of government and/or governance

\section{Experimentation}

- Planned interventions in the social-ecological system, and the monitoring of their results, to learn about ecosystems functioning while managing
Indicators of Operationalization

- Substantive emphasis on the municipal level

- State and federal governments responsible for supervision over legal procedures

- Problems are the responsibility of multiple parties that compete with each other

- Mechanisms for the discussion of novel approaches exist at the state and federal level

- Space for diversity of problem framing and experimentation, including innovative competition, cross-fertilization

- Institutions formed at the river basin scale (e.g. river basin organizations, working groups, conflict resolution mechanisms, research programs)

- Basin-wide plan with common goals and protocols for decision, timing, monitoring

- Basin-wide planning, with explicit considerations of up and downstream consequences of measures

- Citizens/stakeholders have the possibility to influence the way problems are officially defined

- Unrestricted flow of information between Citizens/stakeholders and government bodies

- Various types of information are regarded in the policy making process, including lay knowledge

- Citizens/stakeholders have the legal right to present their views about intended policies at the draft stage and/or to question adopted policies in court

- Making use of various techniques to build consensus and reach agreement, including subdivision and delegation of responsibilities to lower administrative levels

- There is an openness to novel approaches to water management - Novel approaches are introduced on the basis of explicit hypotheses about their intended effects

- The actual effects of novel approaches are monitored and used to evaluate the effectiveness of said approaches

\section{Experimentation}

The experimentation prescription can apply in two ways: (1) in the classical sense of testing hypotheses on the response of the water system to different management interventions; or (2) as the introduction of a certain management approach with subsequent monitoring of the effects and, if needed, adjustment of the approach (Huitema et al. 2009). Water management is typically a political process, in which the implementation of a policy can to some extent be considered as an experiment (Pahl-Wostl 2007, Duit and Galaz 2008). As Plummer and Armitage (2007) point out, ACM needs to be information intensive and learning oriented to deal with complexity and uncertainty, and thus demands a high degree of experimentation to test hypotheses, monitor results, and interpret new approaches (Lee 1993). In addition to producing new ideas and alternatives, experimentation has been associated with agreement on rules, improved procedures, and common values that build cooperation and trust, all essential ingredients in moving from reactive adjustment to proactive anticipation. Well-designed experiments are expected to provide more diverse and flexible governance solutions to adapt to a specific context and create a shared vision that promotes proactive handling of uncertainty and complexity (Walters and Holling 1990, Stankey et al. 2005, Armitage et al. 2008, Klein 2008). Experimentation may face a number of practical difficulties around the choice of methods, the interpretation of results, or the inclusion of stakeholders (Pielke 2007). And also, to prove the worth of a new hypothesis via a political experiment may consume costly time and involve ethical concerns, for example, if the political risk of such management is considered too severe or problems in assessing the effectiveness because changes are not detectable in a reasonable time (Sutherland 2006).

We analyze the application of the four prescriptions during the transition of flood management in the German Rhine basin. They are characterized by institutional and managerial aspects, which we defined and summarized in Table 1 as "characteristic aspects." The "indicators of operationalization" in the second column will be used for the assessment of the degree to which the prescriptions have been followed. We are aware of the lack of an objective, quantitative measure of the prescriptions in enhancing adaptability and in potentially driving policy change. Thus, both, the aspects and the indicators and their links will form the input 
to discuss the role of the prescriptions as facilitators or contributors to the policy changes.

\section{Data collection}

Our empirical findings are based on 38 semistructured interviews, 3 consecutive workshops between 2007 and 2011, and a telephone survey conducted in 2009 and 2010. In addition, official policy documents, legal texts, scientific papers, and documentary reports were analyzed. The semistructured interviews were held with officials responsible for flood management at ministerial, regional, and local administrative levels and with flood experts from academia, citizen initiatives, and NGOs. The questions covered possible triggers of policy change in flood management, i.e., focusing events, such as major floods, elections or political crisis, and change agents or policy entrepreneurs from administration and academia, as well as concomitant circumstances, including the political arenas, where change happened, the values and shortcomings of new concepts and strategies, the current state of flood management, and future challenges. The workshops were organized as part of two projects, ACER (www.adaptation.nl) and NeWater (www.newater.info), in cooperation with the Dutch-German working group on flood management, to develop different adaptation strategies and interventions as responses to future flood risks. Participants of the workshops were delegates from the project partners, flood experts, spatial developers, and decision makers from different administrative levels, representatives from municipalities, citizen initiatives, and NGOs. An important aspect of the workshops was the two-way communication and mutual learning process between the stakeholders, and the possibility of converging opposing positions and perspectives into a joint vision of future flood management (te Linde et al. 2012). The telephone survey was conducted by trained interviewers among 78 communal officials and members of river or dike associations responsible for the local flood management and lasted on average 45 minutes. A questionnaire with 58 questions was used, reviewed beforehand by a multidisciplinary team of experts, and programmed in the statistical software package SPSS, to assess participants' flood risk perception, experience with recent flood events, and the protective capability of their municipality (Becker et al. 2014). To obtain comparable information on the perceptions of an affected but private population group, 11 citizen flood initiatives situated close to the Rhine River were contacted as well. The objective was to get guidance on factors that should be given more attention at the local level to improve the level of preparedness and to prompt action to minimize flood damage. In an "open comment" section, the interviewees could also state their opinion about more general items with regard to flood management, such as trust in the governmental strategy, political focus, and administrative barriers. More detailed results of the empirical research can be found in Becker and Raadgever (2006), Becker et al. (2007, 2014), Raadgever et al. (2007, 2008), Becker (2009), and te Linde et al. (2012).

\section{RESULTS}

How polycentric are the institutional structures?

The division of jurisdictions, in the flood management context, between and within the German federal states is complex. The controlling and strategic power is concentrated at the upper flood administration in the federal states. It is low at the national level, despite the majority of the financial contribution coming from there, and it is limited at the municipal level. However, the position of the local administration becomes stronger during the implementation phase of measures, in accordance with the local spatial development responsibilities and because of the disaster management protocol in the case of flood events. It has been argued that the German federal arrangement is characterized by a polycentric administrative structure with its high degree of interdependence of federal, states (Länder), and local governmental levels and of political and policy interconnections (Neef 2008, 2009, Thiel 2015). This has the disadvantage of limiting or counteracting, to some degree, policy change (Jaenicke et al. 2001, Barzeley and Füchtner 2003, Gunlicks 2005). On the other hand, the institutional setting fosters individual policy developments in each of the federal states, tailored to their problem structures, political configurations, and local interests. Together with the managerial scale, it creates room for experimenting, to produce new ideas, and to review traditional procedures and structures. Such a distribution of power may complicate coordination across jurisdictions and requires considerable vertical and horizontal cooperation (Maynts 1999, Gunlicks 2005), but also offers the chance for mutual learning, for innovating competition, and cross-fertilization resulting in more effective and sustainable management outcomes at different levels (Pahl-Wostl 2007, Ostrom 2010).

In line with the institutional structure, the strategic planning and implementation to reduce flood risk in the Upper Rhine region were distributed over the three federal states concerned: BadenWuerttemberg (B-W), Rhineland-Palatinate (R-P), and Hessen (HE). Each of the states framed the problem differently and applied different strategies to perform the task. BadenWuerttemberg approached it as a multiple task by combining safety and environment. The resulting "Integrated Rhine plan" $(1988,1996)$ aimed to reduce the flood hazard by providing extra water retention in 13 polders (MEBW 2007). At the same time, and promoted by the environmental discourse in the 1970s and the expected European legislation in the 1980s, a complementary environmental objective was agreed to restore the riparian forest. To gain the necessary ecological knowledge and to facilitate the political and public acceptance of the program, the administrative officials formed a coalition with the scientists of the established Auen-Institute of the World Wide Fund for Nature (WWF). Rhineland-Palatinate fulfilled the obligation of additional water storage with 10 retention sites, but in 1994, developed an even more comprehensive flood prevention concept. In addition to technical measures, it addressed the potential negative consequences of flooding by restrictions of spatial developments in flood plains and by assigning individual responsibility to people living in flood prone areas. This added a socioeconomic dimension to the traditional task of engineering flood-based protection and presented a change from the former public safety promise to a new precautionary risk discourse. Hessen decided to take no extra measures because of an assumed lower flood risk and little political interest, but committed to take on a $20 \%$ cost share of the Rhineland-Palatinate retention measures. Independently and at a later stage (1990-1992), North RhineWestphalia (NRW), further downstream in the Lower Rhine, commenced a similar strategic transition from higher dikes toward more space for water and nature restoration, based on its 
"Guidelines for Natural River Training and Maintenance" (MUNLV NRW 2010). North Rhine-Westphalia's "Master Plan for Flood Protection, Ecology and Navigation" (MURL NRW 1992) considered and integrated not only the hydrological but also the socioeconomic and ecological impacts of the planned measures to receive the political support of the related political domains (Becker 2009).

The new flood management policies of the federal states increased the variety of options and strategies that enhanced the flexibility of measures, thereby creating novel opportunities for adaptive solutions. The floods in 1993 and 1995 created the necessary political pressure to consolidate the various approaches and to promote them upward to the national level for German rivers in form of the LAWA "Guidelines for Forward Looking Flood Protection" with its main pillars of ecological water storage, technical and spatial flood prevention, and precautionary damage minimization (LAWA 1995, 2003). To emphasize a coordinated implementation of the guidelines, in particular after the catastrophic River Elbe flood in 2002, the German government confirmed the LAWA guidelines in the "Five Points Program" (BMU 2002) and institutionalized them in 2005 by the first national flood legislation, the Gesetz für den vorbeugenden Hochwasserschutz (BMU 2005). This composite law sets strict rules for spatial development and building in flood prone areas, disaster management, and cooperation between the federal states and forms the basis for the transposition of the EU Flood Directive (European Commission 2007) and the amendment of the Federal Water Act (Wasserhaushaltsgesetz; BMU 2010) in 2010 (Becker 2009, Hartmann 2012).

Signs of disadvantages of the polycentric system are perceptible as well, for example, the late consideration of climate change as a potential issue across the states, or the relatively slow implementation of the water retention projects, i.e., after three decades, only some $50 \%$ of the planned flood retention projects along the German part of the Rhine have been completed (Table 2).

Table 2. Operational retention volumes Mio $\mathrm{m}^{3}$ as percent of the planned capacity (source: IKSR 2006, 2012).

\begin{tabular}{lcccc}
\hline \hline & \multicolumn{4}{c}{$(\%)$ Operational } \\
\cline { 2 - 5 } & 2005 & 2010 & 2020 & $2020+$ \\
\hline $\begin{array}{l}\text { Baden- } \\
\begin{array}{l}\text { Wuerttemberg } \\
\text { Rhineland- }\end{array}\end{array}$ & 40 & 40 & 58 & 100 \\
$\begin{array}{l}\text { Palatinate } \\
\text { North Rhine- }\end{array}$ & 44 & 49 & 98 & 188 \\
$\begin{array}{l}\text { Westphalia } \\
\text { Upper and Lower }\end{array}$ & 40 & 47 & 92 & 121 \\
Rhine & 44 & 78 & 123 \\
\hline
\end{tabular}

The ideas of more space for water, precautionary risk reduction, and green flood protection introduced additional dependencies between the Upper Water Administration of the federal states, where most major flood prevention strategies have their origin, and the communal levels, where responsibility rests for local flood protection, including disaster management, spatial development, and the provision of the local space. The related domains of water management and spatial planning follow a different logic of risk and land use functions, and therefore apply different values, planning procedures, and time horizons (Moss 2004, Van den Brink and Meijerink 2006). This can result in different interests and economic considerations, in difficulties around reserving more space for water retention or controlled flooding, and in missing the chance of an integrated reframing of flood prevention as a spatial planning task (Dister 2002, Röhring 2004, Krieger 2013). There are a number of reasons for the delays or the fading focus in the implementation phase. Apart from the individual interests of local stakeholders, they can be attributed to several often-related political or institutional factors. Frequently voiced criticism in the workshops, interviews, and free comments of the telephone survey included inadequate involvement and delegation of responsibilities at the communal level, insufficient vertical and horizontal interplay within and between the interlinked political domains, and complex and time consuming administrative procedures. Also a lack of urgency in the public and political arena or simply an underrating of the local flood risk has to be noted, particularly after longer periods with no major flood events. The rather optimistic feeling of safety and preparedness of local officials, as revealed in our survey along the Rhine (Becker et al. 2014) is a strong hint that the local risk awareness needs to improve, for example by municipal risk auditing as offered by the Deutsche Vereinigung für Wasserwirtschaft (DWA; http://www.dwa.de). From these findings, we can see (similar to Samuels et al. 2006 and de Kruif 2012) that the administrative structures, including the approval and coordinating procedures, need to be reviewed to speed up the implementation process and better attune projects of the related water-space-nature domains. This, together with an effective transfer of best practices fostered by the mentioned flood associations and partnerships, could be promising steps to strengthen the municipal role in flood risk management (Juepner 2010).

A further complicating factor is the diversity of ownership and use of the land in the different federal states. In BadenWuerttemberg, most of the designated space for retention measures is state property with less than $20 \%$ in private ownership. In cases of locally organized opposition or no amicable settlements with the private owners, the acquisition of storage space in question caused time-consuming expropriation procedures including higher project costs. In RhinelandPalatinate (and similarly in North Rhine-Westphalia), with mostly private property and intensively used farmland in smaller plots, land consolidation procedures could be applied. As Table 2 suggests, this enhanced the acceptance and accelerated the implementation of the measures in Rhineland-Palatinate, inter alia, through simplified approval procedures, early involvement of owner associations in the planning process, and generous relocation of agricultural land holdings (Kaiser 2012).

We also identified in our study the positive impact of what the literature considers to be "critical supporting aspects" in polycentricity: the promoting role of entrepreneurial leadership (Olsson et al. 2006, Huitema and Meijerink 2010) and of crosscutting institutions that are specialized in particular policy matters, in our case, flood risk management (McGinnis and Ostrom 2011). A new generation of experts in the technical administration of the respective federal states acted during the 
transition as policy entrepreneurs. They had an important role in driving change through a fresh management style in special departments that were set up to supervise the new projects. They formed alliances and networks with academia, NGOs, and citizen initiatives to draw on various sources of knowledge, to promote the new ideas, and to gain political and public acceptance. It is important to note that the key operative officials at the Upper Rhine and in North Rhine-Westphalia were present over a long period in leading administrative or academic positions. This gave them the time to learn and to develop the necessary leadership to accompany the transition and maneuver the new concepts upward through the levels of administration. Likewise, they provided a stabilizing element over time with regard to political rearrangements and changing constellations of decision makers (Becker 2009). The other supporting aspect is the establishment in the last three decennia of several statutory corporations, voluntary associations, and community-based organizations to represent the local interests and to strengthen the regional and municipal input in flood prevention. Examples include the Hochwassernotgemeinschaft Rhein, a solidarity association representing some 60 municipalities, cities, NGOs, and more than one million citizens along the Upper and Middle Rhine; several Flood Partnerships; associations of municipalities and cities (Juepner 2010), particularly in the southern parts of the Rhine; the Aktion Blau in Rhineland-Palatinate, in which the regional administration, communities, and citizens cooperate to restore the natural water retention; the Flood Competence Centrum in the city of Cologne with members of policy, science, administration, and the public; or more downstream in North Rhine-Westphalia, the Dutch-German Flood Working Group, triggered by the flood event of 1995 , to share experience and to harmonize cross-border flood prevention (Verwijmeren 2007).

\section{Does management occur at the bioregional level?}

Despite the fact that the Rhine crosses several administrative boundaries, the political responsibility for flood management primarily rests with the individual federal states (Länder), which potentially creates a classic case of ecological misfit. To address this, flood management moved stepwise toward a coordinating bioregional solution to reach a better fit between the relevant jurisdictions (Borowski et al. 2008, Moss 2012, Huitema and Meijerink 2014).

The new flood policies of Baden-Wuerttemberg, RhinelandPalatinate, and North Rhine-Westphalia had been endorsed, but stopped at the borders of the federal states. The flood events of $1993 / 1995$ eventually exerted the political pressure needed to synchronize the individual risk mitigation measures in the Rhine basin. The political arena of the International Commission for the Protection of the Rhine (IKSR) could be used to upscale the ecological retention and risk concept of the federal states, and in 1998, the Action Plan on Floods (FAP) for the Rhine was adopted, to be completed by 2020 within the Rhine 2020 program (IKSR 1995, 1998, 2001a, de Bruin 2006). The FAP represents the core of a bioregional approach with common action targets, firm timings, a budget, and a strict monitoring regime. Although an international program, it can be considered in large part a German project, because around $90 \%$ of existing or planned measures are scheduled to take place in the German part of the basin. The retention projects, the institutional structures, and the responsibilities of the federal states remained unchanged.
However, the combination of the individual measures and the harmonization of the targets stimulated the active interplay between the federal states, sectors, and formal stakeholders. In particular, the monitoring regime of the FAP introduced a basinwide perspective and created a certain discipline that forced the operational actors in each state to reflect on their individual activities and future planning.

At the national level, coordinating fora are established, e.g., the LAWA (State Water Working Group) and more recently and specifically for the Rhine river, the Flussgebietsgemeinschaft Rhein (FGG-Rhein; Rhine River Basin Community), to coordinate the implementation of the FAP, including the monitoring programs, to implement the European water directives, to inform the public, and to prepare the German position for discussions within the IKSR at the basin level.

The IKSR is the supporting coordinating body for the Rhine basin. Its power to determine actions is limited and the implementation of measures remains the responsibility of the respective states (Dieperink 1997, 2000, Kampa et al. 2003, Dombrowsky and Holländer 2004). However, the international authority of the IKSR helps the commission to play an important role by providing the political arena to discuss the required activities and future programs for the basin and to prepare the discussion topics and political decisions for the periodical Rhine Minister Conference. An important link between the states is formed by the IKSR working groups consisting of experts and officials of the riparian states. They deal with technical issues of flood prevention, stipulate research, and the development of complementary risk-reducing activities in the basin. They also serve as the necessary forum, in which formal stakeholders, such as the various associations, e.g., water supply or chemical industry, communal organizations, and environmental NGOs have the right and opportunity to be informed or consulted and, to a lesser degree, influence decisions. Such discussions and decisions are generally led by administrative experts and, as our interviews revealed, with a predominantly political focus and a largely technical flood point of view.

Acknowledging the fact that the IKSR has advisory status only, the progress achieved over the last decades to reduce the flood vulnerability in the basin is remarkable. Effective subprograms have been developed to upgrade flood control. Along the Rhine, flood risk is measured and communicated via the Rhine atlas (IKSR 2001b, 2013a) and standardized hazard and risk mapping (LAWA 2010b, IKSR 2014a) and is translated in additional flood management measures, such as the international flood earlywarning system (Werner et al. 2005, Thielen et al. 2009, IKSR 2012) or emergency and evacuation plans. An assessment of flood risk has been published (IKSR 2006, 2012) and a draft flood management plan was made available in 2014 (IKSR 2014b). Specific research is conducted on the climate change impact on the river discharge pattern by IKSR $(2009,2011)$ or by international and European research projects and case studies, such as the Rhine-Meuse Activity on Flood Risk (IRMASPONGE; Hooijer et al. 2004) or Sustainable Development of Flood Plains (SDF; Menke and Nijland 2008). Supportive scientific knowledge is provided by formal research organizations, such as the International Commission of Hydrology of the Rhine catchment (CHR) or the German Federal Institute of Hydrology (BfG). 
Our investigations also revealed that sovereignty considerations of the federal states are still dominant. The FAP added up the earlier measures and plans of the federal states without reconsidering their design, downstream effects, or protection standards in a basin-wide context. No serious review of the institutional structures, responsibilities, and procedures took place with the aim to create a strong sense of solidarity and cooperation. The administrative borders rather constrain dissemination of knowledge, reflection on experience, and future needs, e.g., climate change adaptation or exchange of best practices and harmonization of standards. They reduce the potential for synergies through joint planning, common use of resources, and restrict the opportunities for mutual learning (Raadgever 2005, Becker 2009, Schmeier 2012). These are the themes of a continuing upstream-downstream discussion, including the issues of the optimal operation of the Upper Rhine retention polders (Homagh and Bremicker 2006, Bronstert et al. 2007), the need to provide extra water storage space upstream to reduce the downstream vulnerability and to get better prepared for potential climate change impacts and extreme flood events, or an eventual increase of dike heights in NRW, which could pose fundamental discharge problems further downstream for the Netherlands (te Linde et al. 2012).

The establishment of the FAP and the obligatory monitoring action initiated a more future-oriented point of view to deal with uncertainty. It became obvious, the FAP might not achieve all of its 2020 targets (IKSR 2006, 2007a, 2012) and that additional retention space, which will also include long-term climate change impacts, needs to be identified.

The introduction of the effects of climate change on the discharge regime in the $\mathrm{Rhine}$ basin happened at a relatively late stage (IKSR $2007 b, 2011,2015)$. For some time, the issue had only been considered regionally for the southern part of the German Rhine in the Klimaveränderung und Wasserwirtschaft (KLIWA) program of Baden-Wuerttemberg, Bavaria, and RhinelandPalatinate (KLIWA 2006). Accordingly, political pressure came from the ministers in charge of the Rhine protection, who drew up a set of demands at their recent meetings: to speed up the implementation of the FAP measures; to identify additional retention space; to investigate the consequences of potential climate change impacts; to further raise the public awareness of flood risk; and to intensify the coordination and cooperation efforts across borders (IKSR 2007b, 2009, 2013b, CHR 2010).

\section{What kind of participation occurs?}

In Germany, formal participation is laid down by law for all major infrastructural projects, including the development of flood management measures such as retention areas and levees. They must go through an extended approval procedure during which the stakeholders and the general public are informed, consulted, and have the opportunity to comment or raise objections. Planning approval decisions can be challenged in court. This creates a formal, top-down understanding of the process management, in which the technical administration dominates the initiating phase. This form of participation can informally be extended, for example by hearings, round tables, and related communication tools to further include the public in the decisionmaking process (Heintz et al. 2012, Kaiser 2012). The exact purpose, scope, and organization of informal, public participation is still under debate (Mostert et al. 2007, Fleischhauer et al. 2012). Frequently, this leads the local stakeholders and the affected public to feel that they are just informed at a (too) late stage and as a matter of compliance with legal obligations (Frijters and Leentvaart 2003, Kampa et al. 2003). Not just NGOs but also district and municipality officials that we interviewed repeatedly expressed their dissatisfaction with one-way information and too little involvement in the planning and decision-making process.

The early strategic development phase of more space for water was characterized by top-down decision making, in which counter arguments of citizens or NGOs were rare. In the more concrete project stages of the 1990s, the local opposition was built up within the legal frame of land-use approval and environmental assessment procedures. The importance of communication and effective process management, the necessity of appreciating the divergent interests, and the relevance to understand the local context became obvious by the turning down of the application for a retention polder near Trebur (State of Hesse) after uncoordinated, insufficient information and consultation management (Becker 2009). A study to investigate the delays of the FAP retention projects within the Integrated Rhine Program in Baden-Wuerttemberg (Ufit 2006) confirmed the difficulty to correct faults of the process management and communication made in the initial project phase and to regain public support at a later stage.

Our observations showed numerous signs of a learning process from positive participation experiences during the last two decades and suggest that many of the above shortcomings in active public involvement are being addressed. In RhinelandPalatinate, a first conventional top-down procedure to develop retention polders at two sites failed because of strong local opposition. In a new approach, a multidisciplinary expert group, including environmental NGOs, investigated several potential retention sites. After an extensive dialogue in an open planning process with the related communities and stakeholders, particularly the farmers, the government designated 10 storage sites (Meuser 2006). This experience of successful participation had a major influence on the future planning and decision processes in Rhineland-Palatinate and increased the productivity of the execution of retention projects, such as Hördt and Ingelheim (Rhineland-Palatinate). At the planned Hördt polder, intensive communication and mediation, but particularly the delegation of responsibilities and power to make decisions given to lower authorities and local social partners enabled the agreement for the first emergency polder in the Rhine basin, scheduled for 2023 (Ness and Schmitteckert 2010). At the Ingelheim polder, transparent planning and communication from the very beginning with all affected stakeholders sped up the implementation process significantly and gained the first local agreement without court proceedings (Kaiser 2012).

In our workshops, flood experts and local officials emphasized the importance of the active participation of the general public to achieve effective flood prevention. Together with the establishment of citizen initiatives and multidisciplinary flood working groups, it fosters the dissemination of local knowledge, and upgrades and complements the communal role in the planning and decision process. For example in Cologne, a city 
periodically affected by heavy flooding, the dedicated city flood authority organized a transparent decision and information process with risk awareness programs and practical emergency exercises. Within a few years, additional retention areas, mobile flood protection, private mitigation measures, and a flood competence center, Hochwasser-Kompetenz-Centrum (HKC), became operational, thus reducing significantly the vulnerability of the city and the region. This result was only achievable, as stated by the head of the flood department, with the active involvement and engagement of the local stakeholders and the affected public. In North Rhine-Westphalia, the technical water administration established alliances between communities, dike associations, and landowners to enhance bottom-up involvement in the early phase of a project. More than $80 \%$ of the land demand for retention areas and infrastructure projects were met by applying important factors for successful participation, such as free flow of information, communal win-win infrastructural projects, generous financial arrangements, and agreed upon compensation schemes, such as relocation of agricultural land holdings. The positive examples in Rhineland-Palatinate and North RhineWestphalia demonstrate that clear rules of collective decision making, distribution of responsibilities between stakeholders and decision makers, and a regulatory compensation framework are promising tools to increase public participation.

\section{Experimentation as part of the management system?}

The task to re-establish the former flood safety standard in a sustainable, ecological manner required innovative technical solutions, a shift in governance, and new policies. This in turn called for intensive experimenting to produce the necessary knowledge for testing novel approaches, trying out alternative institutional arrangements and strategies, and for starting an iterative learning process.

First experimental developments were seen in planning extra space for water and in greening of flood protection. The restoration of floodplains, fluvial forests, wetlands, and the new concept of ecological flooding, as investigated in Altenheim polder (1993-1996), formed the basis for the principle of additional, ecological water storage (Dister 2002, Becker 2009). An automated central system to control the water retention operation was developed and tested and its efficacy verified in combination with the existent dike system (Homagk and Bremicker 2006). The outcome was used in the BadenWuerttemberg in the Integrated Rhine Program $(1988,1996)$ and the Rhineland-Palatinate Retention Program and Aktion Blau (1992, 1994). Likewise, in North Rhine-Westphalia, the Guidelines for Natural River Training and Maintenance were now tested, extended, and applied onto the large-scale waterway of the Lower Rhine (General Plans and Master Plans; StAWA 1990, 1991, MURL NRW 1992). The flood risk reducing effects of consolidated measures in the form of the Action Plan on Floods (FAP) are regularly monitored every five years (IKSR 2012). A start has been made to include climate change as a further risk component in the adaptation strategy of the basin with the study of scenarios for the discharge regime of the Rhine (IKSR 2011) and the climate change adaptation strategy for the IRBD Rhine (IKSR 2015).

Experimentation in a social and institutional sense can be twofold. The risk and precaution related notions, as first formalized in the
LAWA guidelines (LAWA 1995, 2003), initiated a new manner to deal with uncertainty. Guided by the hazard and risk mapping generated along the Rhine, more adaptive strategies and plans were developed to minimize damage and impact of floods, by not only relying on constructive flood control measures but also by implementing soft alternatives. Experimentation is also reflected in the application of a more advanced governance style, including the empowerment of societal partners and building trust among stakeholders, essential aspects for willing support to explore alternatives and achieve consensus as shown by the above examples of Cologne, Ingelheim, or Hördt. Further research, investigations, and developments were (and still are) conducted to integrate soft and hard measures with the aim of increasing adaptability in the basin. Examples include the restoring of flood plains (Dister 2002, Smits and de Groot 2005, Menke and Nijland 2008), more active involvement of spatial development and land use (IRMA-SPONGE, Hooijer et al. 2004), early flood warning systems (Thielen et al. 2009), risk and hazard mapping to increase awareness and prioritize action (IKSR 2014), insurance options (Thieken et al. 2006, Bouwer et al. 2007), and disaster management plans and awareness programs for the affected public (IKSR 2013c).

An important item on the agenda of our workshops was the dispute about the objectives of research and experimentation. The manner of data production, their interpretation, and use led to lively discussions between scientists and practitioners. The majority of scientists argued for independent, objective science and were against testing of hypotheses or experimenting, designed through a pragmatic or even political lens. The flood experts and decision makers, on the other hand, missed the interpretation and guidance, but also the authority of academia. They felt insecure about making decisions or speculating about future requirements, perhaps also shying away from the threat of judicial review. In the end, the participants agreed that this distance between both sides could promote the adherence to proven familiar perspectives, power structures, and management approaches and at the same time, hamper the formulation of new, creative hypotheses and full exploitation of experimentation, thus being counterproductive for adaptability.

\section{DISCUSSION}

Our study demonstrates a transformative policy change in the German Rhine over the last three decades, from the traditional engineering and flood control approach to a more holistic, environmentally oriented concept. The new ecological strategies to reduce flood risk along the Rhine, the redefinition of flood protection as a precautionary risk approach, and the increased procedural efficacy through a more participatory governance style, demonstrate that the ACM prescriptions have been followed. Experimenting and successful learning have been stimulated, thereby creating the scope for enhancing the adaptability of the flood regime (Pahl-Wostl 2009, Pahl-Wostl et al. 2013). The question remains, however, about the specific impact of the policy prescriptions and their role in the success of the transition process and promoters of policy change. Plummer et al. (2012) discuss in detail how difficult, if not impossible, it is to relate operational measures of ACM factors to their outcomes. Swart et al. (2014) warn against the use of largely untested heuristics in adaptation, such as "better adaptation outcomes require stakeholder involvement" or to assume one-size-fits-all 
approaches. Therefore, we are cautious of benchmarking the prescription as drivers or even as a target, but we recognize their initiating, preparing, facilitating, and mediating contributions. Thus, we more generally describe opportunities to promote adaptability and try to link those to our analysis of ACM prescriptions.

\section{Following the prescriptions}

The difficulty with connecting the four ACM prescriptions to specific outcomes is partly conditioned by their ambivalent character. Depending on the respective political or societal context and their specific way of implementation, they can achieve a positive or negative outcome, or they can cause an enhancing but also potentially counterproductive effect. Moreover, the difficulty is underlined by the interrelationship of the prescriptions and by their impact in comparison to other drivers of change.

Polycentricity played an important role in preparing the traditional flood protection regime for change. The responsibilities of and within the autonomous federal states for flood management, in combination with the specific hydrological and biophysical conditions in their river sections forced individual problem framing and stimulated innovative competition between the states to generate the customized solutions. At the same time, it created the room and freedom for experimenting, for reviewing traditional hierarchies and working procedures, and for promoting networking and building of coalitions (Ostrom 2005). New ideas and solutions were presented, such as restoration of flood plains and ecological flooding or controlled retention polders. Considering the more socioeconomic and participatory angle of flood management introduced the precaution, risk, and individual responsibility perspectives. The ability to select from multiple, soft, and hard strategies and adding the various greener, participatory and precautionary elements to the general more space for the water proposition improved the flexibility and enhanced the options for effective and adaptive flood management (Becker 2009). The value of polycentricity was emphasized when the new concepts achieved political acceptance and social goodwill, and could be consolidated and in the end, legally institutionalized at the national level (BMU 2005, 2010). At the same time, a certain imbalance of polycentric governance can be noticed in the limited strategic involvement of the lower administrative level and also in the numerous barriers for taking on more municipal responsibilities (Neef 2008, Becker et al. 2014). A remaining hierarchical governance style, adherence to a strict legal system within jurisdictions, and the time-consuming approval procedures across administrative levels complicate the timely introduction of risk reducing measures, for instance the implementation of water retention space (Table 2). In addition, the interdependencies of flood prevention with water related domains and the need for active interplay across levels and scales appear to be underestimated.

Blomquist and Schlager (2005) appear to have considered polycentric forms of governance and the basin-wide management of water as antagonistic concepts. Polycentricity may facilitate experimentation, multiple strategies and customized solutions, and may promote networking and learning (Pahl-Wostl 2009), but at the same time it protects the individual interests and complicates cooperation, for example in a bioregional approach.
However, the FAP, established in 1998 under the auspices of the IKSR, intensified the bioregional effort of flood control in the Rhine basin. While keeping their political responsibilities for flood management, the federal states could continue their original projects unchanged. However, the integration of the individual retention projects into the FAP contributed to mutual understanding and trust between the federal states. This was needed to harmonize political views and to adapt policies and strategies to the changing conditions and discourses (de Bruin 2006). At the same time, the FAP established a comprehensive regime with an "upstream protects downstream" strategy and with common goals (Hartmann 2012). In particular, the strict monitoring scheme introduced a discipline for updating and reconsidering the risk-reducing program according to new insights, for instance in connection with climate change and possible extreme events. The setup of the regime appears to confirm the view of Imperial and Hennessey (1999) that an institutionally rich environment can produce a high level of collaboration and adaptability. Corrected with the right balance of political control, the institutional diversity in a river basin can even be advantageous. In that respect, the IKSR, with their working groups, fulfills an important role as a coordinating agency, as a forum for knowledge exchange, consultation, communication, and as a contributor to a social-ecological fit in the basin. The question remains as to whether the mandate of the IKSR provides sufficient coordination power in view of a still existing sovereignty thinking of the different actors related to their position in the basin. This has also been noted by the responsible Rhine ministers in their comments, asking for common priority setting, further forward-looking activities in view of expected climate change, and more active discussion in the context of the solidarity and upstream-downstream issue (IKSR 2007b, 2013b).

The legalized formal and increasingly the informal participation did show the potential to effectively influence the noted transition at a range of levels. Our secondary analysis indicates the development toward a more inclusive participatory style of flood management using various techniques and tools, although with varying degrees of success. This becomes even more noticeable considering the links between participation and both the polycentricity and the bioregional prescriptions. A collaborative multilevel environment can foster active participation, whereas traditional hierarchical organizations tend to impede dialogue and effective interplay. Our examples also indicate the fruitful influence of participation on the institutional complexity of polycentric governance regimes. Whereas polycentricity defines the number of actors, their network and interactions within the regime, the participation imperative can influence the frequency and quality of these interactions, the intensity of communication, negotiation and mediation, the mechanism of cooperation, and hence influence the power relations among the actors (Neef 2009, Thiel 2015). First signs of more intensive involvement and deliberation are apparent, for example, Upper authorities did learn and have begun to apply process management with more transparency, open dialogue, and comprehensible communication across disciplines and administrative boundaries. Earlier public information, integration of local capacity, clear compensation rules, and delegation of responsibilities encouraged trust and gained societal support (Becker 2009, Heintz et al. 2012). Community driven institutions, e.g., the Hochwassernotgemeinschaft 
and flood partnerships, or NGOs and citizen initiatives could strengthen the subsidiarity principle to put more emphasis on the municipal level and could assist the coordinating effort of the basin organization (IKSR). The projects of the retention polders Hördt and Ingelheim, or the flood prevention program in the city of Cologne, or the alliances between the water administration, communities, and land owners in North Rhine Westphalia are promising approaches of deliberation and how communal public participation can support quality and productivity in the planning and decision processes. From the extensive comments in our workshops and interviews, however, we have to conclude as well that this style of participation and bottom-up governance is selective and not yet common practice. The rules of the game are still set by the decision makers at higher levels, and the strict interpretation of (in)formal participation frequently serves as a welcome excuse for politicians and officials to provide just the legally required information to the public at the final phase of the approval process. Also, additional questions, such as the correct representation of stakeholders and citizens or the importance and value ascribed to lay knowledge complicate more public involvement in the decision-making processes (Neef 2008). Thus, the form and institutionalization of more extensive public participation in adaptive flood management in a polycentric or in a river basin context as described by the EU Water Directives (EC 2000, 2007) need further development, including a thorough review of institutional structures.

Experimentation could be twofold. First, the test runs carried out and the project examples along the Rhine (Altenheim polder, controlled retention, Aktion Blau, SDF, IRMA-SPONGE, Freude am Fluss) developed the knowledge for new flood management strategies (Dister 2002, Hooijer et al. 2004, Smits and de Groot 2005, Menke and Nijland 2008, Becker 2009). The combination of soft and hard solutions and the integration of safety and nature extended the toolbox of flood risk reducing measures and the possibilities for adaptive solutions. Second, the reflection on former flood events and shortcomings in disaster management provided new insights and hypotheses and led to the introduction of new procedures and policies with the emphasis on precaution and risk, on prevention and recovery (Thieken et al. 2006, Thielen et al. 2009, IKSR 2013c). The policies in the Rhine basin provided a basis for a unified flood management strategy throughout Germany, including the development of flood management plans, rules for spatial development, and instruments for coordination. Thus, experimentation needs to continue, as a sort of umbrella function to further develop and improve the application of the prescriptions, to test hypotheses, and produce the necessary knowledge to, for example, empower participation by investigating how the decision makers can improve the quality of their governance process; how the public will be informed and involved down to the local level (Neef 2009, Fleischhauer et al. 2012); or to promote transboundary cooperation by studying existing path dependency of the entrenched administrative and institutional structures and the necessary adaptation in response to changed awareness and understanding of future challenges (Nees 2009, Thiel 2015).

We would argue that the simultaneous application of the prescriptions, linked and aligned in an effective way, would be a promising option to enhance adaptability. We would also argue that the described failures are signs of a missing balance in the interlinking of actors with diverging interests, often in combination with an unfavorable context (Folke et al. 2005, Becker 2009).

The future operational experience has to prove the success of the policy transition and the new concept with effective coordination among the federal states, harmonized safety standards, and the common interpretation of the future requirements. Concern still remains about the short-term perspectives of experimenting and programs, but also about the slow implementation of new knowledge or best practices of the numerous projects and studies.

\section{Other drivers of change}

The prescriptions we have discussed can largely be classified as institutional, meaning that they refer to the ordering of organizations, rules, policies, and cultures. This is an obvious limitation to our analysis because it largely leaves out agency aspects, and only because of that, is it worth opening the discussion about other aspects that could be of relevance. As policy changes occurred in different federal states (geographical context) and at different times (periodical context), overarching drivers or triggers, such as a high problem pressure, new discourses, and leading actors were necessary to initiate, support, or complete the policy changes as also proposed in the literature (Dombrowsky 2009, Birkmann and al. 2010, Huitema and Meijerink 2010, Voss and Wagner 2010) In our study and particularly at the beginning of the transition, it was a driving combination of the increased flood risk caused by 150 years of human interventions, together with the new public mood of the environmental discourse and political interests. In the follow-up phase, a new cooperative management style of the technical administration took over and their networking activities promoted the new ideas, provided the required knowledge, and gained the political and societal support for the precautionary green flood safety discourse, and more recently the risk-based management approach (e.g., Aerts et al. 2014). Our study reveals the importance of leadership and how the success of experimentation can be supported by learning during the periods of testing and implementing. Later, the transition process was geared by major floods $(1993,1995,2002)$ and by new political configurations, such as elections and new political decision makers (Becker 2009).

The potential impact of climate change and the socioeconomic developments will demand additional decisions and the question remains as to what role $\mathrm{ACM}$ and the prescriptions can play to deal with the future challenges. The present lack of a long-term perspective can be considered a major barrier for the more advanced application of new strategies, or for upgrading existing flood management measures. A flood program with a 100 -year time frame, like the Deltaplan in The Netherlands, and a firm budget would support experimentation and learning, and would lead to a more creative application of the prescriptions by decision makers and local stakeholders alike.

To be effective, new concepts and perspectives in flood management must be transferred and embedded in society at the different administrative and political levels, all the way down to the local stakeholders and affected citizen. At the same time, flood management is still fragmented, and formal procedures of stakeholder involvement and coordination leads to reluctance toward necessary changes (Moss and Huesker 2010). Possible 
bridging procedures (Dieperink et al. 2013) and new modes of collaboration, linking networks and informal learning (PahlWostl et al. 2013) could provide valuable insights in reasons for the slow administrative learning process (Dieperink et al. 2013). The further application of the prescriptions could help to review institutional arrangements, actor constellations, and coordination mechanism and reveal opportunities to improve interplay across levels and sectors, to bundle different sectorial instruments (Von Haaren and Galler 2011), and to speed up decision, approval, and implementation processes.

The concept of risk needs to be revisited in the German context (Klijn et al. 2008, Heintz et al. 2012, Krieger 2013) and the active use of the prescriptions could make a contribution here as well. The current conceptualization adheres basically to the probabilistic HQ100 safety standard, which stands for the recurrence interval of a flood discharge rate occurring statistically every 100 years. The current flood prevention adheres basically on the probabilistic HQ 100 safety standard, which stands for the design standard to provide protection against flood levels that statistically occur once every 100 years. The second aspect of risk, the damaging effects of floods, is often left in the background but demands greater attention. This means not only to concentrate on the reduction of the flood hazard (for example HQ 100), but to also proactively consider the consequences of flooding, including the impact of extreme events and the means to address vulnerability and resilience of the society. This may also avoid excuses to further delay necessary risk reducing investments. This may provide an excuse to further delay investments in flood management. Particularly at the municipal level, it would be helpful to develop a new risk discourse (Becker et al. 2014), increasing the awareness of the communal administration and activating the participation of the local public, and at the same time indicating to the political decision makers the potential needs and priorities for adaptive action. Operational examples are local risk audits and custom-made communication and participation activities.

\section{CONCLUSIONS}

Our results correspond to the four prescriptions in the literature of ACM as a promising approach for managing floods and water resources. The application of the four ACM prescriptions confirmed their usefulness as tools to support discursive change and to offer promising opportunities for better adaptive management of flood risks. In our case study area, the German Rhine, new flood risk reducing measures have been implemented, novel concepts and guiding principles have been drawn up, and new policies have been adopted that have increased the resilience in the basin.

The case study indicated signs of success but also signs of failure in the application of the prescriptions, and the findings showed that the prescriptions remain weak tools if they are not interconnected and reliant on initiation by other change drivers. They are dependent on the respective context of local circumstances and political framework conditions to develop their potential, and they require engaged actors with shared objectives and the help of focusing events to open the window of opportunity.

Thus, it would be shortsighted to assume that the current management system is yet robust and fully prepared to cope with future complexities and uncertain flood risks: Many risk-reducing activities and institutional arrangements still appear to preserve traditional structures and to be more engaged with correcting past errors than with anticipating the future.

We therefore propose further analysis of the institutional arrangements, actors' characteristics and discourses, of their current status, and the desired design, to better understand the different contexts, prescription constellations, and the required further transition steps to enable ACM. Additional research is advocated to investigate the role of coordinated, long term planning as a means to better align the political power and the different interests of actors and to override the tendency for circumstantial drivers, such as flood events, to bring about change. Achieving further benefits from ACM in the Rhine basin is not so much a technical, but rather an institutional, societal task, and political drive to take action is needed rather than waiting and being forced to react by the next major disaster.

\section{Responses to this article can be read online at: http://www.ecologyandsociety.org/issues/responses. $\mathrm{php} / 7562$}

\section{Acknowledgments:}

The authors gratefully acknowledge the constructive comments from Sander Meijerink and the anonymous reviewers of Ecology and Society. The research on which the study is based has been carried out under the framework of the projects ACER and NeWater (6th EU framework program, contract No: 511179). We thank the Dutch BSIK Klimaat voor Ruimte and the European Commission for their financial support.

\section{LITERATURE CITED}

Aerts, J. C. J. H., W. J. W. Botzen, K. Emanuel, N. Ling, H. de Moel, and W. O. Michel-Kerjan. 2014. Evaluating flood resilience strategies for coastal megacities. Science 344(6183):473-475. http://dx.doi.org/10.1126/science.1248222

Andersson, K. P., and E. Ostrom. 2008. Analyzing decentralized resource regimes from a polycentric perspective. Policy Sciences 41(1):71-93.

Armitage, D., F. Berkes, and N. Doubleday, editors. 2007. Adaptive co-management: collaboration, learning, and multi-level governance. UBC Press, Vancouver, British Columbia, Canada.

Armitage, D., M. Marschke, and R. Plummer. 2008. Adaptive comanagement and the paradox of learning. Global Environmental Change 18:86-98. http://dx.doi.org/10.1016/j.gloenvcha.2007.07.002

Armitage, D., and R. Plummer, editors. 2010. Adaptive capacity and environmental governance. Springer-Verlag, Berlin, Germany. http://dx.doi.org/10.1007/978-3-642-12194-4

Armitage, D., R. Plummer, F. Berkes, R. I. Arthur, A. T. Charles, I. J. Davidson-Hunt, A. P. Diduck, N. C. Doubleday, D. S. Johnson, M. Marschke, P. McConney, E. W. Pinkerton, and E. K. Wollenberg. 2009. Adaptive co-management for socialecological complexity. Frontiers, Ecology and the Environment 7 (2):95-102. http://dx.doi.org/10.1890/070089 
Barzeley, M., and N. Füchtner. 2003. Explaining public management policy change: Germany in comparative perspective. Journal of Comparative Analysis: Research and Practice 5:7-27. http://dx.doi.org/10.1080/13876980308412689

Becker, G. 2009. Germany: transitions in flood management in the Rhine basin. Pages 325-348 in D. Huitema and S. Meijerink, editors. Water policy entrepreneurs. A research companion to water transitions around the globe. Edward Elgar, Cheltenham, UK. http://dx.doi.org/10.4337/9781849803366.00031

Becker, G., J. Aerts, and D. Huitema. 2007. Transboundary flood management in the Rhine basin: challenges for improved cooperation. Water Science and Technology 56(4):125-135. http:// dx.doi.org/10.2166/wst.2007.544

Becker, G., J. C. J. H. Aerts, and D. Huitema. 2014. Influence of flood risk perception and other factors on risk-reducing behavior: a survey of municipalities along the Rhine. Journal of Flood Risk Management 7(1):16-30. http://dx.doi.org/10.1111/jfr3.12025

Becker, G., and G. T. Raadgever. 2006. Dutch-German "Arbeitsgruppe Hochwasser," long term flood management in the Lower Rhine region. Interview report. ACER - Developing adaptive capacity to extreme events in the Rhine basin, Amsterdam, The Netherlands. [online] URL: http://library.wur. nl/WebQuery/hydrotheek/2058222

Berkes, F., J. Colding, and C. Folke, editors. 2003. Navigating social-ecological systems: building resilience for complexity and change. Cambridge University Press, Cambridge, UK. http://dx. doi.org/10.1017/cbo9780511541957

Berkes, F., and C. Folke. 1998. Linking social and ecological systems for resilience and sustainability. Pages 1-25 in F. Berkes and C. Folke, editors. Linking social and ecological systems. Management practices and social mechanisms for building resilience. Cambridge University Press, Cambridge, UK.

Bernhardt, C. 2002. PCCP processes in history: the model of the Upper Rhine region. Contribution to the UNESCO-Green Cross International project: from potential conflict to co-operation potential (PCCP). UNESCO, Paris, France. [online] URL: http:// webworld.unesco.org/water/wwap/pccp/cd/pdf/history future shared water resources/pccp processes in history.pdf

Birkmann, J., P. Buckle, J. Jaeger, M. Pelling, N. Setiadi, M. Garschagen, N. Fernando, and J. Kropp. 2010. Extreme events and disasters: a window of opportunity for change? Analysis of organizational, institutional and political changes, formal and informal responses after mega-disasters. Natural Hazards 55:637-655. http://dx.doi.org/10.1007/s11069-008-9319-2

Blomquist, W., and E. Schlager. 2005. Political pitfalls of integrated watershed management. Society and Natural Resources 18(2):101-117. http://dx.doi.org/10.1080/08941920590894435

Borowski, I., J.-P. Le Bourhis, C. Pahl-Wostl, and B. Barraque. 2008. Spatial misfit in participatory river basin management: effects on social learning, a comparative analysis of German and French case studies. Ecology and Society 13(1): 7. [online] URL: http://www.ecologyandsociety.org/vol13/iss1/art7/

Bouwer, L. M., D. Huitema, and J. C. J. H. Aerts. 2007. Adaptive flood management: the role of insurance in Europe. Working paper
W-07/08. Vrije Universiteit, Amsterdam, The Netherlands. [online] URL: http://www.climate-insurance.org/upload/pdf/ bouwer2007 adaptive flood management.PDF

Bronstert, A., A. Bárdossy, C. Bismuth, H. Buiteveld, M. Disse, H. Engel, U. Fritsch, Y. Hundecha, R. Lammersen, D. Niehoff, and N. Ritter. 2007. Multi-scale modelling of land-use change and river training effects on floods in the Rhine basin. River Research and Applications 23:1102-1125. http://dx.doi.org/10.1002/ $\underline{\text { rra. } 1036}$

Bubeck, P. 2013. Private flood mitigation measures in a changing risk environment. Dissertation. VU University Amsterdam, Amsterdam, The Netherlands.

Bulkeley, H., and A. P. J. Mol. 2003. Participation and environmental governance: consensus, ambivalence and debate. Environmental Values 12:143-154. http://dx.doi.org/10.3197/096$\underline{327103129341261}$

Bundesministerium für Umwelt, Naturschutz und Reaktorsicherheit (BMU). 2002. 5-Punkte-Programm der Bundesregierung: Arbeitsschritte zur Verbesserung des präventiven Hochwasserschutzes. Bundesministerium für Umwelt, Berlin, Germany. [online] URL: http://www.umweltbundesamt.de/dokument/5-punkte-programmder-bundesregierung

Bundesministerium für Umwelt, Naturschutz und Reaktorsicherheit (BMU). 2005. Gesetz zur Verbesserung des vorbeugenden Hochwasserschutzes vom 3 Mai 2005. Bundesministerium für Umwelt, Berlin, Germany. [online] URL: http://www.bmub. bund.de/fileadmin/bmu-import/files/pdfs/allgemein/application/pdf/ hochwasserschutzgesetz.pdf

Bundesministerium für Umwelt, Naturschutz und Reaktorsicherheit (BMU). 2010. Wasserhaushaltsgesetz (WHG). Bundesministerium für Umwelt, Berlin, Germany. [online] URL: http://www.bmub. bund.de/detailansicht/artikel/gesetz-zur-neuregelung-des-wasserrechts/

Bund-Länder Arbeitsgemeinschaft Wasser (LAWA). 1995. Guidelines for forward-looking flood protection. Bund-Länder Arbeitsgemeinschaft Wasser, Berlin, Germany. [online] URL: http://www.lawa.de/documents/Leitlinien 2902 629.pdf

Bund-Länder Arbeitsgemeinschaft Wasser (LAWA). 2003. Instruments and guidance for the implementation. Bund-Länder Arbeitsgemeinschaft Wasser, Berlin, Germany.

Bund-Länder Arbeitsgemeinschaft Wasser (LAWA). $2010 b$. Recommendations for the establishment of flood risk management plans. Bund-Länder Arbeitsgemeinschaft Wasser, Dresden, Germany. [online] URL: http://www.lawa.de/documents/LAWA_HWRMPlaene26032010 Text Germany ENG 337.pdf

Bund-Länder Arbeitsgemeinschaft Wasser (LAWA). 2010a. Recommendations for the establishment of flood hazard maps and flood risk maps. Bund-Länder Arbeitsgemeinschaft Wasser, Dresden, Germany. [online] URL: http://www.lawa.de/ documents/LAWA_HWGK15062010_Text_Germany_ENG_f72_4d8. pdf

Cosens, B. A., and M. K. Williams. 2012. Resilience and water governance: adaptive governance in the Columbia River basin. Ecology and Society 17(4): 3. http://dx.doi.org/10.5751/ ES-04986-170403 
de Bruin, D. 2006. Similarities and differences in the historical development of flood management in the alluvial stretches of the Lower Mississippi basin and the Rhine basin. Irrigation and Drainage 55:S23-S54. http://dx.doi.org/10.1002/ird.240

de Kruif, S. 2012. The reflection of normative principles in catchment policies: lessons from the Rhine basin. Thesis. University of Utrecht, Utrecht, The Netherlands. [online] URL: http:// dspace.library.uu.n1/handle/1874/257735

Dieperink, C. 1997. International regime development: lessons from the Rhine catchment area. TDRI Quarterly Review 12:27-35.

Dieperink, C. 2000. Successful International cooperation in the Rhine catchment area. Water International 25(3):347-355. http:// dx.doi.org/10.1080/02508060008686842

Dieperink, C., C. Green, D. Hegger, P. Driessen, M. Bakker, M. van Rijswick, A. Crabbé, and K. Ek. 2013. Flood risk management in Europe: governance challenges related to flood risk management. Report D1.1.2. STAR-FLOOD Consortium, Utrecht, The Netherlands.

Dietz, T., E. Ostrom, and P. C. Stern. 2003. The struggle to govern the commons. Science 302:1907-1912. http://dx.doi.org/10.1126/ $\underline{\text { science. } 1091015}$

Disse, M., and H. Engel. 2001. Flood events in the Rhine basin: genesis, influences and mitigation. Natural Hazards 23:271-290. http://dx.doi.org/10.1023/A:1011142402374

Dister, E. 2002. Gefährdete Landschaften: Vom falschen und richtigen Umgang mit Flüssen und Auen. Pages 112-141 in J. Kachelmann, editor. Die grosse Flut. Rohwohlt Verlag, Reinbeck, Germany.

Dombrowsky, I. 2009. Revisiting the potential for benefit-sharing in the management of trans-boundary rivers. Water Policy 11 (2):125-140.

Dombrowsky, I., and R. Holländer. 2004. Erfahrungen im integrierten Management grenzüberschreitender Flüsse in Europa: Das Beispiel des Rheins. Zeitschrift für angewandte Umweltforschung (ZAU) 15/16:443-459.

Duit, A., and V. Galaz. 2008. Governance and complexity emerging issues for governance theory. Governance: An International Journal of Policy, Administration, and Institutions 21 (3):311-335.

Engle, N. L. 2011. Adaptive capacity and its assessment. Global Environmental Change 21(2):647-656. http://dx.doi.org/10.1016/ j.gloenvcha.2011.01.019

European Commission. 2000. Directive 2000/60/EC of the European Parliament and of the Council of 23 October 2000 establishing a framework for community action in the field of water policy. OJ 22 December 2000 L 327: 1-73. European Commission, Brussels, Belgium. [online] URL: http://eur-lex.europa.eu/legalcontent/EN/TXT/?uri=CELEX:32000L0060

European Commission. 2007. Directive 2007/60/EC of the European Parliament and the Council of 23 October 2007 on the assessment and management of flood risks. OJ 6 November 2007 L288/27-34. European Commission, Brussels, Belgium. [online]
URL: http://eur-lex.europa.eu/legal-content/EN/TXT/?uri= CELEX:32007L0060

European Environment Agency (EEA). 2005. Sustainable use and management of natural resources. European Environment Agency, Copenhagen, Denmark. [online] URL: http://www.eea.europa. eu/publications/eea report 2005 9/download

Fleischhauer, M., S. Greiving, F. Flex, M. Scheibel, T. Stickler, N. Sereinig, G. Koboltschnig, P. Malvati, V. Vitale, P. Grifoni, and K. Firus. 2012. Improving the active involvement of stakeholders and the public in flood risk management - tools of an involvement strategy and case study results from Austria, Germany and Italy. Natural Hazards and Earth System Sciences 12:2785-2798. http:// dx.doi.org/10.5194/nhess-12-2785-2012

Folke, C., S. R. Carpenter, B. Walker, M. Scheffer, T. Chapin, and J. Rockström. 2010. Resilience thinking: integrating resilience, adaptability and transformability. Ecology and Society 15(4): 20. [online] URL: http://www.ecologyandsociety.org/vol15/iss4/ $\underline{\operatorname{art} 20 /}$

Folke, C., T. Hahn, P. Olsson, and J. Norberg. 2005. Adaptive governance of social-ecological systems. Annual Review of Environment and Resources 30:441-473. http://dx.doi.org/10.1146/ annurev.energy.30.050504.144511

Folke, C., L. Pritchard, F. Berkes, J. Colding, and U. Svedin. 2007. The problem of fit between ecological systems and institutions: ten years later. Ecology and Society 12(1): 30. [online] URL: http:// www.ecologyandsociety.org/vol12/iss1/art30/

Frijters, I. D., and J. Leentvaar. 2003. Rhine case study. Contribution to the UNESCO-Green Cross International project: from potential conflict to co-operation potential (PCCP). UNESCO, Paris, France. [online] URL: http://webworld.unesco. org/water/wwap/pccp/cd/pdf/case_studies/rhine2.pdf

Gibson, C., E. Ostrom, and T.-K. Ahn. 1998. Scaling issues in the social sciences. IHDP Working Paper No. 1. International Human Dimensions Program, Bonn, Germany. [online] URL: http:// www.ihdp.unu.edu/docs/Publications/Paper/Paper Scaling issues in the social sciences.pdf

Gleick, P. H. 2003. Global freshwater resources: soft-path solutions for the 21st century. Science 302:1524-1528. http://dx. doi.org/10.1126/science.1089967

Guerin, K. 2007. Adaptive governance and evolving solutions to natural resource conflicts. NZ Treasury working paper 07-03. New Zealand Treasury, Wellington, New Zealand. [online] URL: https://editorialexpress.com/cgi-bin/conference/download.cgi?db_name= NZAE2007\&paper id=64

Gunlicks, A. B. 2005. German Federalism and recent reform efforts. German Law Journal 6(10):1283-1296. [online] URL: https://www.germanlawjournal.com/pdfs/Vol06No10/ PDF Vol 06 No 10 1283-1296 SI Articles Gunlicks.pdf

Gustafson, B. 1998. Scope and limits of the market mechanism in environmental management. Ecological Economics 24:259-274. http://dx.doi.org/10.1016/S0921-8009(97)00147-X

Hajer, M. A., and H. Wagenaar, editors. 2003. Deliberative policy analysis: understanding governance in the network society. Cambridge University Press, Cambridge, UK. http://dx.doi. org/10.1017/cbo9780511490934 
Hartman T. 2012. Land policy for German rivers: making space for the rivers. Pages 121-133 in J. F. Warner, A. van Buuren, and J. Edelenbos, editors. 2012. Making space for the river: governance experiences with multifunctional river flood management in the $U$. $S$. and Europe. IWA, London, UK.

Heintz, M. D., M. Hagemeier-Klose, and K. Wagner. 2012. hv a risk governance culture in flood policy - findings from the implementation of the "Floods Directive" in Germany. Water 4:135-156. http://dx.doi.org/10.3390/w4010135

Hill, M. 2012. Navigating complex choices in adaptive capacity and water governance. Adaptive capacity in two contrasting water governance regimes in relation to flooding and drought: the cases of Aconcagua Chile and the Rhone in Switzerland. Dissertation. University of Geneva, Geneva, Switzerland.

Hill, M. 2013. Adaptive capacity of water governance: cases from the Alps and the Andes. Mountain Research and Development 33 (3):248-259. http://dx.doi.org/10.1659/mrd-journal-d-12-00106.1

Holling, C. S., editor. 1978. Adaptive environmental assessment and management. John Wiley and Sons, London, UK.

Homagk, P., and M. Bremicker. 2006. Steuerungsstrategien für die Rückhaltemaßnahmen am Oberrhein; Upstream downstream issues. Pages 1-10 in Proceedings zum Kongress Wasser. 3-7 April 2006 Berlin, Germany.

Hooijer, A., F. Klijn, G. B. M. Pedroli, and A. G. Van Os. 2004. Towards sustainable flood risk management in the Rhine and Meuse river basins: synopsis of the findings of IRMA-SPONGE. River Research and Applications 20:343-357. http://dx.doi. org/10.1002/rra.781

Huitema, D., and S. Meijerink. 2010. Realizing water transitions: the role of policy entrepreneurs in water policy change. Ecology and Society 15(2): 26. [online] URL: http://www.ecologyandsociety. org/vol15/iss2/art26/

Huitema, D., and S. Meijerink, editors. 2014. The politics of river basin organisations: coalitions, institutional design choices and consequences. Edgar Elgar, Cheltenham, UK. http://dx.doi. org/10.4337/9781782549222

Huitema, D., M. van de Kerkhof, and U. Pesch. 2007. The nature of the beast: are citizens' juries deliberative or pluralist? Policy Sciences 40(4):287-311.

Huitema, D., E. Mostert, W. Egas, S. Moellenkamp, C. PahlWostl, and R. Yalcin. 2009. Adaptive water governance: assessing the institutional prescription of adaptive (co-) management from a governance perspective and defining a research agenda. Ecology and Society 14(1): 26. [online] URL: http://www.ecologyandsociety. org/vol14/iss1/art26/

Imperial, M. T. 2005. Using collaboration as a governance strategy: lessons from six watershed management programs. Administration and Society 37(3):281-320. http://dx.doi. org/10.1177/0095399705276111

Imperial M. T., and T. Hennessy. 1999. Environmental governance in watersheds: collaboration, public value, and accountability. Paper presented at the Twenty-First Annual Research Conference of the Association for Public Policy Analysis and Management, 4-6 November, 1999. Association for Public Policy Analysis and Management, Washington, D.C., USA.
Ingram H. 2011. Beyond universal remedies for good water governance: a political and contextual approach. Pages 241-261, in Garrido A., and H. Ingram, editors. 2011. Water and Food in a changing world, Roudledge, New York, USA.

International Commission for the Hydrology of the Rhine Basin (CHR). 2010. Assessment of climate change impacts on discharge in the Rhine River Basin: Results of the RheinBlick2050 Project. Report No. I-23. International Commission for the Hydrology of the Rhine Basin, Lelystad, The Netherlands.

Internationale Kommission zum Schutze des Rheins (IKSR). 1995. Grundlagen und Strategie zum Aktionsplan Hochwasser. Internationale Kommission zum Schutze des Rheins, Koblenz, Germany. [online] URL: http://www.gbv.de/dms/goettingen/198442173. pdf

Internationale Kommission zum Schutze des Rheins (IKSR). 1998. Aktionsplan Hochwasser (Action Plan on Flood Defense). Internationale Kommission zum Schutze des Rheins, Koblenz, Germany.

Internationale Kommission zum Schutze des Rheins (IKSR). 2001a. Atlas 2001. Internationale Kommission zum Schutze des Rheins, Koblenz, Germany.

Internationale Kommission zum Schutze des Rheins (IKSR). 2001b. Rhein 2020 - Programm zur nachhaltigen Entwicklung des Rheins. Internationale Kommission zum Schutze des Rheins, Koblenz, Germany. [online] URL: http://www.iksr.org/index. php?id=30\&sword list $[0]=$ rhein\&sword list $[1]=2020 \& \mathrm{~L}=3 \& \mathrm{cHash}=$ a3afb858536815524967381914c2e306

Internationale Kommission zum Schutze des Rheins (IKSR). 2006. Nachweis der Wirksamkeit von Massnahmen zur Minderung der Hochwasserstände im Rhein infolge der Umsetzung des Aktionsplans Hochwasser bis 2005. Report 153d. Internationale Kommission zum Schutze des Rheins, Koblenz, Germany.

Internationale Kommission zum Schutze des Rheins (IKSR). 2007a. Umsetzung des Aktionsplans Hochwasser bis 2005. Report 156d, 157d. Internationale Kommission zum Schutze des Rheins, Koblenz, Germany.

Internationale Kommission zum Schutze des Rheins (IKSR). 2007b. Living and linking Rhine - common challenge of a watershed. Pages in Conference of Rhine Ministers, 18 October 2007, Bonn, Germany. Internationale Kommission zum Schutze des Rheins, Koblenz, Germany. [online] URL: http://www.iksr. org/fileadmin/user_upload/Dokumente_en/MIN07-02e.pdf

Internationale Kommission zum Schutze des Rheins (IKSR). 2009. Analyse des Kenntnisstands zu den bisherigen Veränderungen des Klimas und zu den Auswirkungen der Klimaänderung auf den Wasserhaushalt im Rhein-Einzugsgebiet, Literaturauswertung. Report 174. Internationale Kommission zum Schutze des Rheins, Koblenz, Germany. [online] URL: http://www.iksr.org/uploads/ $\underline{\text { media/Bericht } 174 \text { d 01.pdf }}$

Internationale Kommission zum Schutze des Rheins (IKSR). 2011. Study of scenarios for the discharge regime of the Rhine. Report 188. Internationale Kommission zum Schutze des Rheins, Koblenz, Germany. [online] URL: http://www.iksr.org/fileadmin/ user upload/Dokumente en/Reports/188 e.pdf 
Internationale Kommission zum Schutze des Rheins (IKSR). 2012a. Nachweis der Wirksamkeit von Maßnahmen zur Minderung der Hochwasserstände im Rhein. Umsetzung des Aktionsplans Hochwasser 1995-2010 einschließlich Vorausschau für 2020 sowie 2020+. Report 199. Internationale Kommission zum Schutze des Rheins, Koblenz, Germany.

Internationale Kommission zum Schutze des Rheins (IKSR). 2012b. Aktionsplan Hochwasser 1995-2010: Handlungsziele, Umsetzung und Ergebnisse, Kurzbilanz. Report 200. Internationale Kommission zum Schutze des Rheins, Koblenz, Germany.

Internationale Kommission zum Schutze des Rheins (IKSR). 2013a. Report on the determination of potential significant flood risk areas in the international river basin district Rhine. FD-1st Report. Internationale Kommission zum Schutze des Rheins, Koblenz, Germany. [online] URL: http://www.iksr.org/fileadmin/ user upload/Dokumente en/Reports/FD-1st report 01.pdf

Internationale Kommission zum Schutze des Rheins (IKSR). 2013b. Rheinmininisterkonferenz, 28 Oktober 2013, Basel, Switzerland. Internationale Kommission zum Schutze des Rheins, Koblenz, Germany. [online] URL: http://www.news.admin.ch/ NSBSubscriber/message/attachments/32460.pdf

Internationale Kommission zum Schutze des Rheins (IKSR). 2013c. Bericht über die Bestimmung der potenziell signifikanten Hochwasserrisikogebiete in der internationalen Flussgebietseinheit Rhein. Report HWRM-RL-1. Internationale Kommission zum Schutze des Rheins, Koblenz, Germany. [online] URL: http:// www.iksr.org/fileadmin/user_upload/Dokumente de/Berichte/HWRMRL-1._Bericht 01.pdf

Internationale Kommission zum Schutze des Rheins (IKSR). 2014a. Bericht über die Erstellung der Hochwassergefahren - und Hochwasserrisikokarten in der internationalen Flussgebietseinheit Rhein' (Einzugsgebiet > $2500 \mathrm{~km}^{2}$, Teil A) und den Informationsaustauschnach Artikel6 Abs. 2 der EG-Richtlinie über die Bewertung und das Management von Hochwasserrisiken (HWRM-RL). Abschlussbericht (Stand: 22. März 2014). Internationale Kommission zum Schutze des Rheins, Koblenz, Germany.

Internationale Kommission zum Schutze des Rheins (IKSR). 2014b. Entwurf: Hochwasserrisiko-managementplan für die Internationale Flussgebietseinheit Rhein, Teil A, Stand 17. Dezember 2014. Internationale Kommission zum Schutze des Rheins, Koblenz, Germany. [online] URL: http://www.iksr.org/ fileadmin/user_upload/Dokumente_de/Rhein_Aktuell/HWRMPLAN 2014 Entwurf.pdf

Internationale Kommission zum Schutze des Rheins (IKSR). 2015. Strategy for the IRBD Rhine for adapting to climate change. Report 219. Internationale Kommission zum Schutze des Rheins, Koblenz, Germany. [online] URL: http://www.iksr.org/fileadmin/ user upload/Dokumente en/Reports/219 en.pdf

Jänicke M., H. Jörgens, K. Jörgensen, and R. Nordbeck. 2001. Governance for sustainable development in Germany: institutions and policy making. Forschungsstelle für Umweltpolitik, Berlin, Germany. [online] URL: http://egovdev.ro/sites/default/files/ documente/rapoarte/216-dezvdurabila-germania.pdf

Jüpner, R. 2010. Hochwasserpartnerschaften zur Koordinierung grenzüberschreitender Hochwasservorsorge. BWK-Bundeskongress
23-25.September 2010, Duisburg, Germany. [online] URL: $\underline{\text { http:// }}$ www.bwk-bund.de/fileadmin/Dokumente/Veranstaltungen/ Kongresse/2010/18--Juepner-Hochwasserpartnerschaften.pdf

Kaiser, C. 2012. Umsetzung von Hochwasservorsorge und Hochwasserschutz mit Hilfe integrierter ländlicher Entwicklung am Beispiel der technischen Polderbauwerke und Deichrückverlegungen am Oberrhein. Thesis. University of Applied Science Mainz, Mainz, Germany.

Kampa, E., N. Kranz, and W. Hansen. 2003. Public participation in river basin management in Germany: "from borders to natural boundaries". Report of work package 4 of the HarmoniCOP project. [online] URL: http://http://www.ecologic.eu/6929

Klein, A. 2008. Judging as nudging: new governance approaches for the enforcement of constitutional social and economic rights. Columbia Human Rights Law Review 39:351-422.

Klimaveränderung und Wasserwirtschaft (KLIWA). 2006. Climat change in Southern Germany: extent - consequences strategies. Impact on water resources management. Report 2006. Klimaveränderung und Wasserwirtschaft, Offenbach, Germany. [online] URL: http://www.kliwa.de/download/Climate Changein Southern Germany.pdf

Krieger, K. 2013. The limits and variety of risk-based governance: the case of flood management in Germany and England. Regulation and Governance 7(2):236-257. http://dx.doi.org/10.1111/ $\underline{\text { rego. } 12009}$

Kundzewiecz, Z. W., editor. 2012. Changes in flood risk in Europe. IAHS, Wallingford, Oxfordshire, UK.

Lebel, L., P. Garden, and M. Imamura. 2005. Politics of scale, position and place in the governance of water resources in the Mekong region. Ecology and Society 10(2): 18. [online] URL: http://www.ecologyandsociety.org/vol10/iss2/art18/

Lebel L., T. Grothmann, and B. Siebenhüner. 2010. The role of social learning in adaptiveness: insights from water management. International Environmental Agreements: Politics, Law and Economics 10:333-323. http://dx.doi.org/10.1007/s10784-010-9142-6

Lee, K. N. 1993. Compass and gyroscope: integrating science and politics for the environment. Island, Washington D.C., USA.

Maynts, R. 1999. Multi-level governance: German federalism and the European Union. Pages 101-114 in C. Lankowsky, editor. Governing beyond the Nation-State: global public policy, regionalism or going local?. Report No 11. American Institute for Contemporary German Studies, Washington, D.C., USA. [online] URL: http://www.aicgs.org/site/wp-content/uploads/2011/11/ governance.pdf

McGinnis, M. D. 2000. Polycentric games and institutions: readings from the workshop in political theory and policy analysis. University of Michigan Press, Ann Arbor, Michigan, USA.

McGinnis, M. D. 2005. Costs and challenges of polycentric governance. Workshop on analyzing problems of polycentric governance in the growing EU, Humboldt University, 16-17 June 2005, Berlin, Germany.

McGinnis, M. D., and E. Ostrom. 2011. Reflections on Vincent Ostrom, public administration, and polycentricity. Public Administration Review 72(1):15-25. 
Menke, U., and H. Nijland. 2008. Nature development and flood risk management combined along the River Rhine - experiences from a transnational co-operation within the SDF-project. Pages 330-338 in B. Gumiero, M. Rinaldi, and B. Fokkens, editors. Proceedings of the 4th ERRC international conference on river restoration, 16-21 June 2008. San Servolo, Venice, Italy. [online] URL: https://www.bfn.de/fileadmin/MDB/documents/themen/ wasser/teil02_6_nijland.pdf

Merz, B., J. Hall, M. Disse, and A. Schumann. 2010. Fluvial flood risk management in a changing world. Natural Hazards and Earth Systems Sciences 10:509-527. http://dx.doi.org/10.5194/nhess-10-509-2010

Meuser, A. 2006. Bau der rheinland-pfälzischen Rückhaltungen am Oberrhein - von der Vision zur Realität. Pages 73-84 in N. Busch and Y. Strunck, editors. Gewässerkundliche Untersuchungen für verkehrliche und wasserwirtschaftliche Planungen an Bundeswasserstraßen. Bundesanstalt fur Gewässerkunde, Koblenz, Germany.

Ministerium für Umwelt und Naturschutz, Landwirtschaft und Verbraucherschutz des Landes Nordrhein-Westfalen (MUNLV NRW). 2010. Richtlinie für den naturnahen Ausbau und Unterhalt der Fliessgewässer in NRW (Guidelines for natural river training and maintenance of water flow in NRW). Ministerium für Umwelt und Naturschutz, Landwirtschaft und Verbraucherschutz des Landes Nordrhein-Westfalen, Düsseldorf, Germany. [online] URL: http://www.lanuv.nrw.de/veroeffentlichungen/sonderreihen/ blau/Blaue\%20Richtlinie.pdf

Ministerium für Umwelt, Raumordnung und Landwirtschaft des Landes Nordrhein-Westfalen (MURL NRW). 1992. Gesamtkonzept Rhein in Nordrhein-Westfalen: Hochwasser, Ökologie, Schiffahrt: Grundlagen. Ministerium für Umwelt, Raumordnung und Landwirtschaft des Landes Nordrhein-Westfalen, Düsseldorf, Germany. [online] URL: http://www.nr-feldmann.de/Doku/ Behoerden/Stresstest $\%$ 201-1992.pdf

Ministry of the Environment Baden-Wuerttemberg (MEBW). 2007. The integrated Rhine programme. Flood control and restoration of former floodplains along the Upper Rhine. 2nd edition. Baden-Wuerttemberg, Ministry of the Environment, Climate Protection and the Energy Sector, Stuttgart, Germany.

Moss, T. 2004. The governance of land use in river basins: prospects for overcoming problems of institutional interplay with the EU Water Framework Directive. Land Use Policy 21:85-94. http://dx.doi.org/10.1016/j.landusepol.2003.10.001

Moss, T. 2012. Spatial fit, from panacea to practice: implementing the EU Water Framework Directive. Ecology and Society 17(3): 2. http://dx.doi.org/10.5751/es-04821-170302

Moss, T., and F. Hüesker. 2010. Wasserinfrastrukturen als Gemeinwohltrüger zwischen globalem Wandel und regionaler Entwicklung - institutionelle Erwiderungen in Berlin-Brandenburg. Discussion Paper 03/2010 (4). Berlin-Brandenburgische Akademie der Wissenschaften, Berlin, Germany.

Mostert, E. 2003. The challenge of public participation. Water Policy 5:179-197.

Mostert, E., C. Pahl-Wostl, Y. Rees, B. Searle, D. Tàbara, and J. Tippett. 2007. Social learning in European river basin management: barriers and supporting mechanisms from 10 river basins. Ecology and Society 12(1): 19. [online] URL: http://www. ecologyandsociety.org/vol12/iss1/art19/

Munaretto, S., and D. Huitema. 2012. Adaptive comanagement in the Venice lagoon? An analysis of current water and environmental management practices and prospects for change. Ecology and Society 17(2): 19. http://dx.doi.org/10.5751/ ES-04772-170219

Neef, A. 2008. Lost in translation: the participatory imperative and local water governance in North Thailand and Southwest Germany. Water Alternatives 1(1):89-110. [online] URL: http:// dlc.dlib.indiana.edu/dlc/handle/10535/6282

Neef, A. 2009. Transforming rural water governance: towards deliberative and polycentric models? Water Alternatives 2 (1):53-60. [online] URL: http://dlc.dlib.indiana.edu/dlc/handle/10535/6387

Ness A., and M. Schmitteckert. 2010. Abschlussbericht zur Steuerungsgruppe Ökologische Flutungen im geplanten Reserveraum für Extremhochwasser in der Hördter Rheinniederung. Institut für Umweltstudien Weibel and Nees, Heidelberg, Germany.

Olsson, P. 2007. The role of vision in framing adaptive comanagement processes: lessons from Kristianstads Vattenrike, Southern Sweden. Pages 268-285 in D. Armitage, F. Berkes, and N. Doubleday, editors. Adaptive co-management: collaboration, learning, and multi-level governance. UBC Press, Vancouver, British Columbia, Canada.

Olsson, P., L. H. Gunderson, S. R. Carpenter, P. Ryan, L. Lebel, C. Folke, and C. S. Holling. 2006. Shooting the rapids: navigating transitions to adaptive governance of social-ecological systems. Ecology and Society 11(1): 18. [online] URL: http://www. ecologyandsociety.org/vol11/iss1/art18/

Ostrom, E. 1999. Coping with the tragedies of the commons. Annual Revue of Political Science 2:493-535. http://dx.doi. org/10.1146/annurev.polisci.2.1.493

Ostrom, E. 2005. Understanding institutional diversity. Princeton University Press, New Haven, Connecticut, USA.

Ostrom, E. 2007. A diagnostic approach for going beyond panaceas. Proceedings of the National Academy of Sciences 104 (39):15181-15187. http://dx.doi.org/10.1073/pnas.0702288104

Ostrom, E. 2010. Beyond markets and states: polycentric governance of complex economic systems. American Economic Review 100:641-672. http://dx.doi.org/10.1257/aer.100.3.641

Pahl-Wostl, C. 2007. Transitions towards adaptive management of water facing climate and global change. Water Resources Management 21:49-62. http://dx.doi.org/10.1007/s11269-006-9040-4

Pahl-Wostl, C. 2009. A conceptual framework for analyzing adaptive capacity and multi-level learning processes in resource governance regimes. Global Environmental Change 19:354-365. http://dx.doi.org/10.1016/j.gloenvcha.2009.06.001

Pahl-Wostl, C., L. Lebel, C. Knieper, and E. Nikitina. 2012. From applying panaceas to mastering complexity: toward adaptive water governance in river basins. Environmental Science and Policy 23:24-34. http://dx.doi.org/10.1016/j.envsci.2012.07.014

Pahl-Wostl, C., G. Becker, C. Knieper, and J. Sendzimir. 2013. How multilevel societal learning processes facilitate transformative 
change: a comparative case study analysis on flood management. Ecology and Society 18(4): 58. http://dx.doi.org/10.5751/ ES-05779-180458

Pielke, Jr., R. A. 2007. The honest broker: making sense of science in policy and politics. Cambridge University Press, Cambridge, UK. http://dx.doi.org/10.1017/cbo9780511818110

Plummer, R., and D. Armitage. 2007. A resilience-based framework for evaluating adaptive co-management: linking ecology, economy and society in a complex world. Ecological Economics 61:62-74. http://dx.doi.org/10.1016/j.ecolecon.2006.09.025

Plummer, R., B. Crona, D. R. Armitage, P. Olsson, M. Tangö, and O. Yudina. 2012. Adaptive comanagement: a systematic review and analysis. Ecology and Society 17(3): 11. http://dx.doi. org/10.5751/ES-04952-170311

Plummer, R., D. R. Armitage, and R. C. de Loë. 2013. Adaptive comanagement and its relationship to environmental governance. Ecology and Society 18(1): 21. http://dx.doi.org/10.5751/ ES-05383-180121

Raadgever, G. T. 2005. Transboundary river basin management regimes: the Rhine basin case study. Background report to deliverable 1.3 .1 of the NeWater project. RBA centre, Delft University of Technology, Delft, The Netherlands. [online] URL: http://www.citg.tudelft.nl/fileadmin/Faculteit/CiTG/Over_de_faculteit/ Afdelingen/Afdeling watermanagement/Secties/waterhuishouding/ Leerstoelen/Waterbeheer/People/old/Raadgever, G.T./doc/ D131 Rhine Final.pdf

Raadgever, T., J. Aerts, K. Rasche, G. Becker, S. Rotter, H. Buiteveld, and A. te Linde. 2007. Protokol workshop 2: Szenarien und Strategien für ein erfolgreiches (Hoch-) Wassermanagement im Rhein 24 April 2007, Papendal, The Netherlands. Vrije Universiteit Amsterdam and Technische Universiteit Delft, The Netherlands and Seecon Deutschland GmbH, Osnabrück, Germany.

Raadgever, T., P. Bubeck, S. Rotter, E. Interwies, G. Becker, J. Aerts, and A. te Linde. 2008. Minutes of workshop 3, Flood management strategies for the Rhine: devising and evaluating measures in consideration of climate change and socio-economic developments 16 April 2008, Cologne, Germany. Vrije Universiteit Amsterdam and Technische Universiteit Delft, The Netherlands and Seecon Deutschland GmbH, Osnabrück, Germany.

Reed, M. S. 2008. Stakeholder participation for environmental management: a literature review. Biological Conservation 141:2417-2431. http://dx.doi.org/10.1016/j.biocon.2008.07.014

Renn, O. 2014. Stakeholder involvement in risk governance. Ark Group, London, UK.

Röhring, A. 2004. Institutional interplay: Anwendung eines institutionentheoretischen Untersuchungsansatzes in der raumwissentschaftlichen Forschung am Beispiel von Landwirtschaft und Gewässerschutz. UFZ Report 7/2004: proceedings of a workshop 26-27 June 2003. UFZ, Leipzig, Germany.

Sabatier, P. A., W. Focht, M. Lubel, Z. Trachtenberg, A. Vedlitz, and M. Matlock, editors. 2005. Swimming upstream: collaborative approaches to watershed management. MIT Press, Cambridge, Massachusetts, USA.
Sadoff, C. W., and D. Grey. 2002. Beyond the river: the benefits of cooperation on international rivers. Water Policy 4:389-403. http://dx.doi.org/10.1016/S1366-7017(02)00035-1

Samuels, P., F. Klijn, and J. Dijkmann. 2006. An analysis of the current practice of policies on river flood risk management in different countries. Irrigation and Drainage 55:S141-S150. http:// dx.doi.org/10.1002/ird.257

Scarlett, L. 2013. Collaborative adaptive management: challenges and opportunities. Ecology and Society 18(3): 26. http://dx.doi. org/10.5751/es-05762-180326

Schlager, E., and W. Blomquist. 2000. Local communities, policy prescriptions, and watershed management in Arizona, California, and Colorado. Paper in Constituting the commons: crafting sustainable commons in the new millennium. Eighth Conference of the International Association for the Study of Common Property, 31 May-4 June, 2000, Bloomington, Indiana, USA. Indiana University, Bloomington, Indiana, USA. [online] URL:http:// hdl.handle.net/10535/2133

Schmeier, S. 2012. Navigating cooperation beyond the absence of conflict: mapping determinants for the effectiveness of river basin organisations. International Journal of Sustainable Society 4 (1/2):11-27. http://dx.doi.org/10.1504/ijssoc.2012.044662

Schultz, L., A. Duit, and C. Folke. 2011. Participation, adaptive co-management, and management performance in the world network of biosphere reserves. World Development 39(4):662-671. http://dx.doi.org/10.1016/j.worlddev.2010.09.014

Smit, B., and J. Wandel. 2006. Adaptation, adaptive capacity and vulnerability. Global Environmental Change 16:282-292. http://dx. doi.org/10.1016/j.gloenvcha.2006.03.008

Smits, A. J. M., and W. de Groot. 2005. Freude am Fluss: rivierbeheer als kans voor locale gemeenschappen. Pages 39-47 in M. Vos, editor. Alle zeilen bijzetten; water en ruimtelijke kwaliteit in de regio. NIROV, Den Haag, The Netherlands.

Sovacool, B. K. 2011. An international comparison of four polycentric approaches to climate and energy governance. Energy Policy 30:3832-3844. http://dx.doi.org/10.1016/j.enpol.2011.04.014

Staatliches Amt für Wasser- und Abfallwirtschaft Düsseldorf (StAWA). 1990. Generalplan Hochwasserschutz am Niederrhein. Düsseldorf, Germany.

Staatliches Amt für Wasser- und Abfallwirtschaft Bonn (StAWA). 1991. Generalplan Hochwasserschutz am Rhein im Regierungsbezirk Köln. Bonn, Germany.

Stankey, G. H., R. N. Clark, and B. T. Bormann. 2005. Adaptive management of natural resources: theory, concepts, and management institutions. General Technical Report PNWGTR-654. United States Department of Agriculture, Portland, Oregon, USA. [online] URL: http://www.fs.fed.us/pnw/pubs/ pnw gtr654.pdf

Sutherland, W. J. 2006. Predicting the ecological consequences of environmental change: a review of the methods. Journal of Applied Ecology 43(4):599-616. http://dx.doi.org/10.1111/ j.1365-2664.2006.01182.x 
Swart R., R. Biesbroek, and T. C. Lourenço. 2014. Science of adaptation to climate change and science for adaptation. Frontiers in Environmental Science 2(29):1-8. http://dx.doi.org/10.3389/ fenvs.2014.00029

Tàbara, J. D., and C. Pahl-Wostl. 2007. Sustainability learning in natural resource use and management. Ecology and Society 12(2): 3. [online] URL: http://www.ecologyandsociety.org/vol12/iss $2 /$ $\underline{\operatorname{art} 3 /}$

te Linde, A. H. 2011. Rhine at risk?: impact of climate change on low-probability floods in the Rhine basin and the effectiveness of flood management measures. Dissertation. VU University Amsterdam, Amsterdam, The Netherlands. [online] URL: $\underline{\text { http:// }}$ hdl.handle.net/1871/19453

te Linde, A.H., E.J. Moors, P. Drogers, B. Bisselink, G. Becker, H. ter Maat, and J.C.J.H. Aerts. 2012. ACER: developing adaptive capacity to extreme events in the Rhine basin. National Research Programme Climate changes Spatial Planning (KvR). Report 046/12. The Netherlands.

Thieken, A. H., T. Petrow, H. Kreibich H., and B. Merz. 2006. Insurability and mitigation of flood losses in private households in Germany. Risk Analysis 26:383-395. http://dx.doi.org/10.1111/ j.1539-6924.2006.00741.x

Thiel, A. 2015. Constitutional state structure and scalar reorganization of natural resource governance: the transformation of polycentric water governance in Spain, Portugal and Germany. Land Use Policy 45:176-188. http://dx.doi.org/10.1016/j. landusepol.2015.01.012

Thielen, J. Bartholmes, M.-H. Ramos, and A. de Roo. 2009. The European Flood Alert System - part 1: concept and development. Hydrology and Earth System Sciences 13:125-140. http://dx.doi. org/10.5194/hess-13-125-2009

Toonen, T. 2010. Resilience in public administration: the work of Elinor and Vincent Ostrom from a public administration perspective. Public Administration Review 70:193-202. http://dx. doi.org/10.1111/j.1540-6210.2010.02147.x

Umweltbundesamt (UBA). 2010. Water resources management in Germany Part 1 Fundamental. Umweltbundesamt, Dessau, Germany. [online] URL: https://www.umweltbundesamt.de/sites/ default/files/medien/publikation/long/3770.pdf

Umweltforschungsinstitut (Ufit). 2006. Component B5: Das integrierte Rheinprogram IRP in Baden-Württemberg: Kommunikation, Beteiligung, Akzeptanz. "Freude am Fluss"/Component B: Development of a joint Planning method. Ufit umweltforschungsinstitut, Leutershausen, Germany.

United Nations Economic Commission for Europe (UNECE). 2009. Guidance to water and climate change. Convention on the protection and use of transboundary watercourses and international lakes. United Nations Economic Commission for Europe, Geneva, Switzerland. [online] URL: http://www.unece. org/?id=11658

Van de Kerkhof, M. 2006. A dialogue approach to enhance learning for sustainability. A Dutch experiment with two participatory methods in the field of climate change. Integrated Assessment Journal 6(4):7-34. [online] URL: http://journals.sfu. ca/int assess/index.php/iaj/article/viewArticle/236

Van den Brink, M., and S. Meijerink. 2006. Implementing policy innovations. Resource dependence, struggle for discursive hegemony and institutional inertia in the Dutch river policy domain. Research group governance and places $(\mathrm{GaP})$, University of Nijmegen, Working Paper Series 2006/2. Radboud University Nijmegen, Nijmegen, The Netherlands. [online] URL: http://repository.ubn. ru.nl/bitstream/handle/2066/45540/45540.pdf

Verwijmeren, J. 2007. Cross border co-operation and the DutchGerman working group on high water. Pages 93-118. In Verwijmeren, J., and M. Wiering, editors. 2007. Many rivers to cross, cross border co-operation in river management. Eburon Academic Publishers, Delft, The Netherlands.

Von Haaren, C., and C. Galler. 2011. Zukunftsfähiger Umgang mit Wasser im Raum. Akademie für Raumforschung und Landesplaning, Hannover, Germany.

Voss, M., and K. Wagner. 2010. Learning from (small) disasters. Natural Hazards 55:657-669. http://dx.doi.org/10.1007/s11069-010-9498-5

Walker, B., C. S. Holling, S. R. Carpenter, and A. Kinzig. 2004. Resilience, adaptability and transformability in social-ecological systems. Ecology and Society 9(2): 5. [online] URL: http://www. ecologyandsociety.org/vo19/iss2/art5/

Walters, C. J., and C. S. Holling. 1990. Large-scale management experiments and learning by doing. Ecology 71:2060-2068. http:// dx.doi.org/10.2307/1938620

Werner, M., P. Reggiani, A. de Roo, P. Bates, and E. Sprokkereef. 2005. Flood forecasting and warning at the river basin and at the European scale. Natural Hazards 36:25-42. http://dx.doi. org/10.1007/s11069-004-4537-8

Winnegge, R., and T. Maurer. 2002. Water resource management, country profile Germany. Global Runoff Data Centre (GRDC) Federal Institute of Hydrology (BfG), Koblenz, Germany. [online] URL: http://www.bafg.de/GRDC/EN/02 srvcs/24 rprtsrs/ report 27.pdf? blob=publicationFile

Witter, J. V., H. T. C. van Stokkom, and G. Hendriksen. 2006. From river management to river basin management: a water manager's perspective. Hydrobiologia 565:317-325. http://dx.doi. org/10.1007/s10750-005-1922-6

Young, O. R. 2002. Institutional dimensions of environmental change: fit, interplay, and scale. MIT Press, Cambridge, Massachusetts, USA.

Young, O. R., F. Berkhout, G. C. Gallopin, M. A. Janssen, E. Ostrom, and S. van der Leeuw. 2006. The globalization of socioecological systems: an agenda for scientific research. Global Environmental Change, 16:304-316. http://dx.doi.org/10.1016/j. gloenvcha.2006.03.004 